UNITED STATES ATOMIC ENERGY COMMISSION

KINETICS OF THE ALKYLATION AND ACYLATION OF NICKEL DIPIVALOYLMETHIDE

BY

K. E. Johnson

G. S. Hammond

July 1959

Ames Laboratory

Iowa State University

Ames, Iowa

Technical Information Service Extension, Oak Ridge, Tenn. 
IS -215

11

F. H. Spedding, Director, Ames, Laboratory.

Work performed under Contract. No. W-7405-eng-82. 
IS -215

iii

TABLE OF CONTENTS

ABSTRACT

INTRODUCTION

HISTORICAL

EXPERIMENTAL

RESULTS AND DISCUSSION
Page

vi

1

3

14

34

B.9.9 


\title{
KINETICS OF THE ALKYLATION AND ACYLATION
}

\section{OF NICKEL DIPIVALOYLMETHIDE*}

\author{
K. E. Johnson and G. S. Hammond
}

\section{ABSTRACT}

A study was made of the reactions of nickel dipivaloylmethide with the following reagents: tirphenylmethyl chloride, benzoyl chloride,

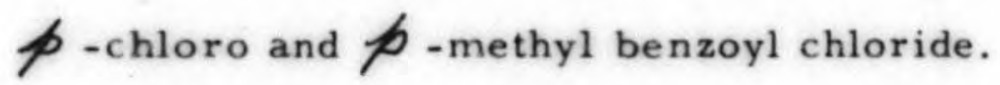

Infrared spectra of the easily hydrolyzed product of tritylation seem to indicate that the enol ether, the product of O-alkylation, is formed. The acyl hal des react to give the triketones. The latter have been characterized by spectra and $\mathrm{C}, \mathrm{H}$, analysis.

The kinetics of all the reactions studied were found to settle down to a second order rate law after a fast initial reaction. The rate law is illustrated by Equation (11).

$$
\text { (11) rate }=k_{2}\left[\mathrm{Ni}(\mathrm{DPM})_{2}\right] \quad[\mathrm{R}-\mathrm{C} 1] .
$$

The trilylation did not take place at $50^{\circ}$ when the reaction flask was flushed with nitrogen..

These reactions are catalyzed by aluminum chloride and nickel pivalate. The acylations are catalyzed by an impurity in the acyl chloride. When benzoyl chloride with different purity was used, the second order

* This report is based on a Ph. D. thesis by K. E. Johnson submitted July, 1959, to Iowa State University, Ames, Iowa. This work was done under contract with the Atomic Energy Commission. 
rate constant for the benzoylation of nickel DPM ranged from 0.02-0.20. The rate of $p$-methoxybenzoylation is the same as that for benzoylation. The $p$-chlorobenzoylations studied were about twice as fast. The fast rate of the latter was attributed to the presence of a higher percentage of catalyst, which is probably the acid.

The air oxidation of nickel dipivaloymethide was found to compete with the acylations under the conditions of these studies. An investigation of this phenomenon showed that nickel pivalate is the major product. Pivalic acid was also detected in the product mixture. This oxidation takes place in chlorobenzene and in aromatic hydrocarbons. It occurs in cyclohexane when small amounts of benzoyl chlorides are present.

These results might be explained by the following sequence of reactions:
(1) $\mathrm{Ni}(\mathrm{DPM})_{2}+2 \mathrm{RCOOH}$
$\longrightarrow \quad 2 \mathrm{H}-\mathrm{DPM}+\mathrm{Ni}^{+} \mathrm{RCOO}_{2}$

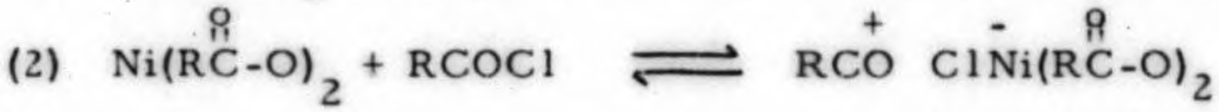

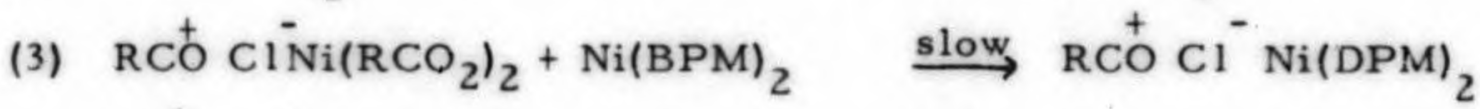
(4) $\mathrm{RCO}^{+} \mathrm{Cl}^{-} \mathrm{Ni}(\mathrm{DPM})_{2}+\mathrm{RCOC} 1$ $\stackrel{\text { fast }}{\longrightarrow}$ Products
(5) $\stackrel{2}{\stackrel{\circ}{C} \mathrm{Cl}}+\mathrm{Ni}_{(\mathrm{DPM})} \stackrel{\text { slow }}{\longrightarrow} \mathrm{RCO}_{2}^{+} \mathrm{Cl}^{-} \mathrm{Ni}(\mathrm{DPM})_{2}$
(6) $\mathrm{RCO}^{+} \mathrm{Cl}^{-} \mathrm{Ni}(\mathrm{DPM})_{2} \stackrel{\text { fast }}{\longrightarrow}$ Products
(7) $\mathrm{RCO}^{+} \mathrm{Cl} \mathrm{Ni}(\mathrm{RCOO})_{2}$ $\mathrm{RCO}_{+}^{+} \mathrm{Cl}^{-} \mathrm{Ni}(\mathrm{DPM})_{2}+\mathrm{O}_{2} \longrightarrow$ Oxidation products 


\section{INTKO TCION}

The present knowledge of the chemistry of metal ion complexes has emanated princlpally from two general areas of study. The first of these includes investigations of the thermodynamic and chemical properties of metal complexes with common 1norganic nucleophilic ligands. Product analysis and stereochemical analysis have been the most effective tools for the study of substitution reactions which these metal complexes undergo. A second major field of interest has centered around the use of organic compounds for complexing and separating metal ions. Nost of the work in this fleld has resulted from efforts of analysts in their search for those reagents which have specific properties that make them valuable as reagents for quantitative separations of metal 1ons. Imminent among these reagents are the various oxime derivatives and ethylenediamine derivatives.

These studies have been restricted to aqueous or partially aqueous media in which the rates of reaction are too fast to be studied by conventional methods of kinetic analysis. Consequently, the study of the mechanfsms of substitution reactions of metal complexes has been restricted to a very few cases.

Many metals can be converted to cheletes of $\beta$-diketones which are soluble in organic solvents. The reactions of such 
chelates with various reagents are slow enough to be studied kinetically.

It is the purpose of this work to present a formal kinetic study of the rates of acylation and alkylation of metal complexes with enolate anfons derlved from $\beta$-diketones and make some attempt to clarify the mechanisms of the reactions.

Most of these studies were carried out on the nickel(II) chelate of $2,2,6,6$-tetramethyl-3,5-heptadione (d1p1valoylmethane, DPM). The a1r oxidation of this compound proved quite interesting and a report of a brief investigation of this phenomenon is included herein. 
HSTORZCAL

Study of the mechanisms of substitution reactions of metallic elements has been restricted to a very small number of complexes and compoinds ${ }^{1}, 2$. Find work consisted of stereochemical investigations and the study of tre relative rates of reaction of metel ions and conmon anions with netal complexes wich themsezres have common anions as 11 gands. The ruactions studied have been almost exclusively those Involving excharije of metel ions or tae exchanje of one or more of lne 11 ands between the various compounds. These reactions may be classified more specifically as i) substitution reacions and 2) oxication reduction reactions. Aqueous or partially aqueous solvents were used in most cases.

\section{Substitution Reactions of Metrl Complexes}

Substitution reactions of metal coordination compounds are conveniently described as nucleophilic substitutions $\left(S_{N}\right)$ and electrophilic substitutions $\left(\mathrm{S}_{\mathrm{E}}\right)$. This terminology is synonymous with that developed by Hughes and Ingold in their description of organic reactions ${ }^{3}$. At least two fundamentally different patinays could be followed in substitution ractions.

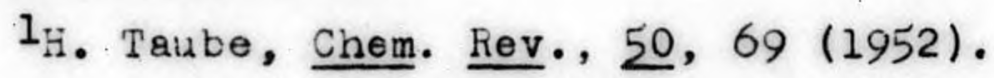

2F. Easolo and R. Pearson, "Mechanisms of Inorganic Reactions", John W1ley and Sons, Inc., New York (1958).

${ }^{3} \mathrm{c}$. K. Ingold, "Structure and Mechanisms in Oranic Compounds", Corneli University Press, Ithaca (1953). 


\section{3}

These are labeled as dissociation $\left(\mathrm{S}_{\mathrm{N}} l, \mathrm{~S}_{\mathrm{E}} l\right)$ and displacement $\left(\mathrm{S}_{\mathrm{N}}{ }^{2}, \mathrm{~S}_{\mathrm{E}}{ }^{2}\right)$ mechanisms.

Basolo and Pearson 4 discussed several criterla for the two mechanisms. The effects of varying the sizes and charges of the central atoms and the leaving groups in octahodral complexes, tend to fit the requirements of an $\mathrm{S}_{\mathrm{N}} \mathrm{l}$ mechanism. On the other hand, it was found that the line of demarcation between labile and inert complexes falls at the point where the Inner d-orbitals become at least singly occupied. This can be reasonably explained by an $\mathrm{S}_{N} 2$ mecinanism, since the Introduction of anotior group into the coordination sphere 1s greatly aided if an empty lower d-orbital is available. Brown and Ingold found that substitutions of chloro groups in cobalt( $I L I$ ) complexes proceed uy an $S_{N} I$ mechanism. But, these could be described as an $\mathrm{S}_{\mathrm{N}} 2$ mechanism involving the solvent as the nucleophilic reagent. A number of haloammine complexes of platinum(IV), with nucleophilic reagents showed second order behavior 5 .

The existence of $\mathrm{S}_{\mathbb{N}} 1, \mathrm{~S}_{N} 2$, and borderline mechanisins between these two has been discovered in studies of substitution reactions of square planar complexes of platinum(II) 7 .

4Basolo and Pearson, op. cit., p. 895.

5D. D. Brown and C. K. Incold, J. Chem. Soc., 2574 (1953).

6O. E. Zvyagintsev and E. F. Karardashova, Doklady Akad. Nauk S.S.S.R., 108, $4 / 7$ (1956).

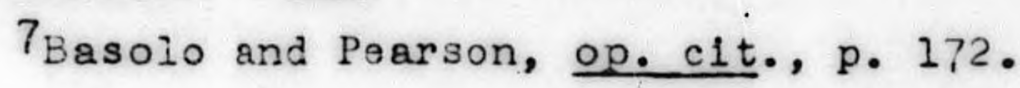


Calkins and Hall ${ }^{8}$ followed the kinetics of the exchenge of nickel(II) between $\mathrm{Ni}(\mathrm{CN}) 4^{-2}$ and amino acld complexes of nickel(II) by observing the exchange of radioactive nickel. They found the reaction to be first order in each reactant. Consequently, they postulated an $\mathrm{S}_{\mathrm{N}} 2$ mechanism for the reaction.

Oxidation-Reduction Reactions of Metal Complexes

Redox reactions are often subdivided into electron transfer reactions and atom transfer reactions. There is evidence that the former do occur in gaseous systems. No real evidence for electron transfer in solution has been advanced.

Taube and his coworkers 9 have demonstrated the transfer of oxygen atoms in the oxidation of sulfites and nitrites with hypochlorous acid. Using chromium(II) cation as a reducing agent, they effected the transior of a large number of univalent atoms and groups ${ }^{10}$.

\section{Metal Chelates of $\beta$-Diketones}

Many metals have been converted to oll-soluble metal chelates of $\beta$-diketones. The physical and thermodynamic prop-

\section{$5028(1958)$.

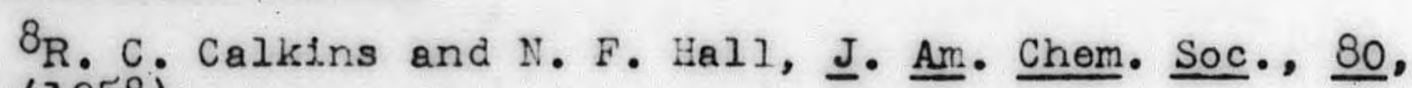
$9_{\mathrm{H}}$ Taube, Record Chem. Prog. Kresge-Hooker Sc1. L1b., 17. 25 (1956).

\footnotetext{
$10_{\mathrm{H}}$. Taube, H. Neyers and R. L. Rich, I. Am. Chem. Soc.,
} 15. 4118 (1953). 
erties of those chelates have been thoroughly investigated. Van U1tert and Fernelius 11,12 have studied the relative stabilities of chelates of -diketones. The following values of $\log \mathrm{K}$ (formation constant) for metal chelates of dibenzoylmethane were reported: $\mathrm{L1}^{+} 5.95, \mathrm{Na}^{+} 4.18, \mathrm{~K}^{+} 3.62, \mathrm{Rb}^{+} 3.52$, $\mathrm{Cs}^{+}$3.42. These values which were obtalned by potentiometric messurements on several $\beta$-diketone-metal solutions, seem to indicate that the stability is a function of the size of the metal 1ons. A comparison of the cholating tendencies of a serles of bivalent metals toward several p-diketones gave the following general order of increasing stabilities: $\mathrm{Ba}, \mathrm{Sr}$, $\mathrm{Ca}, \mathrm{Mg}, \mathrm{Cd}, \mathrm{Mn}, \mathrm{Pb}, \mathrm{Zn}, \mathrm{Co}, \mathrm{N} 1, \mathrm{Fe}, \mathrm{Cv}, \mathrm{Be}, \mathrm{Hg}$. A plot of log $K$ versus electronegativity of the metals is linear except for Be.

The thermal stabilities of several metal acetylacetonates have been invest1gated by Charles and coworkers ${ }^{13}, 14$. Acetone and carbon dioxide gases were emitted as the main products when metal acetylacetonates were decomposed in the

$1 I_{W}$. Conard Fernelius and Le Grand G. Van U1tert, Acta. Chem. Scand., $\underline{8}, 1726$ (1954).

${ }^{12}$ Le Grand G. Uitert, W. Conard Fernellus and Bodie F. Douglas, I. Am. Chem. Soc., 75, 2736 (1953).

13 Joan Von Hoene, Robert G. Charles and William M. Hickam, J. Phys. Chom., 62, 315 (1958).

14 Robert G. Charles and Sidney Barnartt, J. Phys. Chom., 62, 257 (1958). 
absence of oxygen. The following or der of decreasing stabilities of several metals wa based on the emission of gaseous products at $350^{\circ}$ : $\mathrm{Na}(I), \mathrm{Cr}$ (III), Al(III), N1(II), $\mathrm{Cu}(I I), \mathrm{Fe}(I I), \mathrm{Fe}(I I I), \mathrm{Co}(I I), \mathrm{Co}$ (III), Mn(III).

The infrared spectra of metal chelates of $\beta$-diketones are characterized by strong absorption bands in the 1550-1600 $\mathrm{cm}^{-1}$ and 1280-1390 $\mathrm{cm}^{-1}$ regions ${ }^{15}$. Bands in this region of the spectra have been assigned to stretching of the carbonoxygen and carbon-carbon bonds of the chelate ring ${ }^{16}$. Most of these compounds also show strong absorption in the visible range.

Hammond and coworkers 17,18 have found that the following metal chelates are easily prepared and purifled.

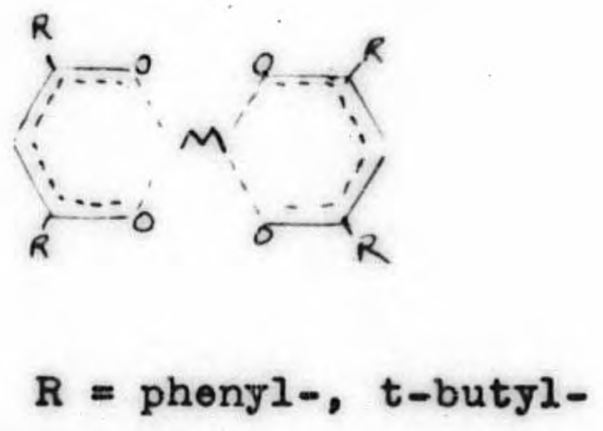

15L. J. Bellamy and L. Boecher, J. Chom. Soc.. 4487 (1954). 16. Meoke and E. Funk, $\underline{z}$. Electrochom., 60, 1124 (1956). $17 \mathrm{G}$. S. Hammond and A. W. Fort, Data from studies of metal chelates, Research notebook, U. S. Atom1c Fnergy Commission, Ames Laboratory, Ames, Iowa (1953). 18 G. A. Guter and G. S. Hanmond, J. Am. Chem. Soc.. 81, 46824689 (1959). 
These chelates are thermally stable, 11ght resistant, and react relatively slowly with varlous organic reagents and with lodine. The method of purification and the melting points of some of these metal chelates are given in Table 1.

Table 1. Propertles of metal chelates of $\beta$-diketones

\begin{tabular}{|c|c|c|}
\hline Formula $a^{a}$ & Method of purification ${ }^{b}$ & Molting point \\
\hline $\mathrm{NaDPM}$ & Sublimation & Dec. $300^{\circ}$ \\
\hline$M_{g}(D P M)_{2}$ & Petroloum ether & $135-137^{\circ}$ \\
\hline $\mathrm{Ca}(\mathrm{DPM})_{2}$ & Ethanol-water & $232-233^{\circ}$ \\
\hline $\mathrm{Cu}(\mathrm{DPM})_{2}$ & Dimethyl formamide & $197-198^{\circ}$ \\
\hline $\mathrm{Cu}(\mathrm{BPM})_{2}$ & Ligroin & $203^{\circ}$ \\
\hline $\mathrm{Cu}(\mathrm{DBM})_{2}$ & Toluene & $296^{\circ}$ \\
\hline $\mathrm{N}_{1}(\mathrm{DPM})_{2}$ & Subilmation & $222-225^{\circ}$ \\
\hline $\mathrm{Zn}(\mathrm{DPM})_{2}$ & Sublimation & $144^{\circ}$ \\
\hline $\mathrm{Al}(\mathrm{DPM})_{3}$ & Ethanol & $264-265^{\circ}$ \\
\hline $\mathrm{Fe}(\mathrm{DPM})_{3}$ & D1me thyl forman1 de & $167^{\circ}$ \\
\hline $\mathrm{Ho}(\mathrm{DPM})_{3}$ & D1methyl forman1de & $154-155^{\circ}$ \\
\hline
\end{tabular}

${ }^{2} \mathrm{DPM}=\left[\mathrm{M}_{3} \mathrm{CCOCHCOCM}_{3}\right], \mathrm{DBM}=\left[\mathrm{C}_{6} \mathrm{H}_{5} \mathrm{COCHCOC}_{6} \mathrm{H}_{5}\right]$, BPM $=\left[\mathrm{C}_{6} \mathrm{H}_{5} \mathrm{COCHCOCM} 3\right]$.

becrystallization from the indicated solvents or vacuum aublimation. 
A qualitative survey of several reactions which these chelates undergo in nonhydroxyl1c solvents has been made by Hammond and Nonhebel ${ }^{19}$.

\section{Reactions of chelates with ac1ds}

Metal chelates are very rapldy hydrolyzed when shaked with aqueous solutions of mineral aclds or when anhydrous hydrogen halldes are bubbled tirrough the solutions. The hydrolysis products are the $\beta$-diketones, from which the chelates are derived, and metal salts of the acids.

Nearly all of the chelates invest1gated reacted immeasurably rap1d w1th $\rho$-nitrophenol, 2, 4-dinitrophenol and p1cric ac1d. Aluminum diplvaloylmethane (DPM) reacted slowly with picric ac1d. Ferric and mercurlc DPM gave no observable reaction with any of the n1trophenols.

Reactions of metal chelates w1th lodine

All of the metal chelates except ferric DPM and aluminum DPM react with lodine in benzene. The stolchlometry of this reaction seems to be one mole of lodine per mole of chelate. The metal lodide has been isolated in $85 \%$ yleld accounting for essentlally all of the reacted lodine. No organle compounds were 1solated.

$19 \mathrm{G}$. S. Hammond and D. R. Nonhebel, Data from studies of metal chelates, Research notebook, U. S. Atomic Energy Commission, Ames Laboratory, Ames, Iowa (1958). 


\section{Fieactions with alkyl halides}

Several metal chelates have been reacted with alkgl halldes, lncluding methyl lodide and triphenylmethyl chloride. Products of both 0-alkylation and C-alkylation are obtained along with the metal salts. N1ckel DPM reacts with triphenylmethyl chloride to give the enol ether. The following sequence is in the decreasing order of reactivity of triphenylmethyl chloride with various metal chelates derived from DPM and BPM (benzoylp1.valoylmethane): zinc, barlum, potassium, nickel and copper.

\section{Reactions of metal chelates with acyl chlorides}

Metal chelates react with acyl chlorides to give triketones, the C-acylated product, and enol esters, the 0acylated product. Any correct prediction as to where a specific acyl hallde will attach the substrate seems to be a fortultous guess. Evidence for this $1 \mathrm{~s}$ shown in Table 2 which 11sts varlous reactions of metal chelates with acyl hal1des. The following order of decreasing reactivities was observed In the reaction of metal chelates with benzoyl chloride: potassium $>$ barlum $>$ stront1um $>$ lanthnum $>$ erblum $>$ calc1um $>$ alnc $>$ nickel > sodium $>$ magneslum $>$ copper $>$ aluminum $>1$ ron. 
Table 2. Reactions of motal cholates with acyl halldes

\begin{tabular}{|c|c|c|}
\hline Metal chelate & Acyl halldo & Product \\
\hline $\mathrm{Cu}(\mathrm{DPM})_{2}$ & Benzoyl chloride & Triketone \\
\hline$N_{1}(D P M)_{2}$ & Benzoyl chlor 1 de & Triketone \\
\hline $\mathrm{Zn}(\mathrm{DPM})_{2}$ & Benzoyl chiorlde & Enol ester \\
\hline $\mathrm{Zn}(\mathrm{DPM})_{2}$ & $\rho$-N1trobenzoyl chlor1de & Tr1ketone \\
\hline $\mathrm{N} 1(\mathrm{DPM})_{2}$ & P-N1trobenzoyl chloride & Triketone \\
\hline L1 (BPM) & P1valoyl chloride & Enol ester \\
\hline $\mathrm{Ca}(\mathrm{DPM})_{2}$ & P1valoyl chloride & Triketone \\
\hline $\mathrm{Fe}(\mathrm{DPM})_{3}$ & Benzoyl chloride & No reaction \\
\hline$A 1(D P M)_{3}$ & Benzoyl chloride & No reaction \\
\hline
\end{tabular}

In an attempt to gain some 1nsight as to the mechan1 am of the reaction of metal chelates with alkglating and acylating agenta, Hammond and Nonhebel made qualitative comparison of substituent, solvent and catalytic effects ${ }^{20}$. Table 3 shows the orders of reactivities in the reactions of the chelates with substituted benzoyl chloride in dry benzene. The rates of reaction of metal chelates with acyl and a $1 \mathrm{kyl}$ chlorides 1ncreased w1th increasing polarity or basity of the solvent. The addition of aluminum chloride or silver perchlorate accelerated the reaction.

20D. R. Nonhobel, Data rrom studies of motal chelates, Research notebook, U. S, Atomic Energy Comm1salon, Ames Laboratory, Ames, Iown (1958). 
Table 3. Reactions of metal chelates with substituted benzoyl chloride in dry benzene

Metal chelate

Decreasing rate of reaction

$\begin{array}{ll}\text { Colcium } & \rho-\mathrm{NO}_{2}>\mathrm{H}>\rho-\mathrm{OCH}_{3} \\ \text { Copper } & \rho-\mathrm{NO}_{2}>\mathrm{H}>\rho-\mathrm{OCH}_{3} \\ \text { Nickel } & \rho-\mathrm{NO}_{2}>\mathrm{H}>\rho-\mathrm{OCH}_{3} \\ \text { Zine } & \rho-\mathrm{OCH}_{3}>\mathrm{H}>\rho-\mathrm{NO}_{2} \\ \text { Aluminum } & \rho-\mathrm{OCH}_{3}>\mathrm{H}>\rho-\mathrm{NO}_{2}\end{array}$

The obvious conclusions which can be drawn from the present knowledge of the alkylation and acylation of metal chelates is that there is a significant variation in mechanisms of reactions involved.

A1r 0xidation of Metal Chelates of $\boldsymbol{\beta}$-Diketones

Charles and Barnartt2l found that the reaction of metallic 1ron with acetylacetone 1s greatly accelerated by the presence of oxygen. Substantial amounts of acet1c and pyruvic ac1ds were produced as by-products. These products were also obtalned from the alr oxidation of $\mathrm{Fe}(\mathrm{II})$ acetylacetonate, leading Charles and Barnartt to the conclusion that $\mathrm{Fe}$ (II) acetylacetonate is an 1ntermediate in the for-

21 Robert G. Charles and S1dney Barnartt, J. Phys. Chem., 62, 252 (1958). 
mation of $\mathrm{Fe}($ III) acetylacetonate.

A study of the acylation and alkylation of metal chelates In the presence and absence of oxygen might concelvably provide some hint as to the characterization of the mechanisms of these reactions. 


\section{EXPERIMENTAL 22}

Chemicals

\section{Aluminum chloride}

Anhydrous aluminum chloride (Reagent Grade, J. T. Baker Chemical Company) was used without further purification.

\section{Ammon1a}

Anhydrous ammonia (The Mathison Company, Inc.) was used without further purification.

\section{Ansole}

An1sole (Reagent Grade, Matbeson, Coleman, and Bell) was used without further purification.

\section{Benzene}

Thlophene free benzene (Allied Chemical and Dye Company) was distilled from sodium or phosphorus pentachloride.

\section{Benzorl chloride}

Reagent grade benzoyl chloride (J. T. Baker Chemlcal Company) was used without further purification.

\section{Chlorobenzene}

Reagent grade chlorobenzene (Allied Chemical and Dye Company) was distilled through a spinning band column. The

22 All melting points and bolling points reported in this report are uncorrected. 
fraction used distilled at $132^{\circ}$.

\section{P-Chlorobenzoyl chloride}

Reagent gradef-chlorobenzoyl chloride (Eastman White Label, Eastman Kodak Company) was used without further purification.

\section{Cumene}

Feagent grade cumene (Allied Chemlcal and Dye Company) was purified by Richard Tunder, Department of Chemistry, Californ1a Institute of Technology, Pasadena, California. The material was treated with sulfuric acid until coloration disappeared. It was then washed clean of acid and distilled through a glass bead column. The fraction bolling at $151-153^{\circ}$ was used.

\section{Cyclohoxane}

Cyclohexane (Reagent Grade, Math1son Chemical Company) was distilled from sodium metal. The bolling point was $80^{\circ}$.

\section{Diethyl ether}

Reagent grade diethyl ether (Matheson, Coleman, and Bell) was used without further purification.

\section{Lithlum motal}

L1thium wire (L1thium Corporation of Amer1ca, Inc.) was cleaned with petroloum ether. 


\section{P-Methoxrbenzorl chloride}

Reagent grade $f$-methoxybenzoyl chloride (Matheson, Coloman, and Bell) was distilled through a spinning band column. The fraction bolling at $120-122^{\circ}$ at $10 \mathrm{~mm}$. was used.

\section{N1ckelous acetate tetrahydrate}

Reagent grade nickelous acetate tetrahydrate (J. T. Baker Chemical Company) was used without further purification.

\section{N1trobenzene}

N1trobenzene (Reagent Grade, Matheson, Coleman, and Bell) was used without further purification.

\section{p-N1trobenzorl chloride}

Reagent gradep-nitrobenzoyl chloride (Matheson, Coleman, and $B e 11)$ was recrystallized from a $50 \%$ methanol-diethyl ether solution. The melting point was $72^{\circ}$.

\section{Phonol}

Technical grade phenol (Matheson, Coleman, and Bell) was used without further purification.

\section{P1nacolone}

P1nacolone (Technlcal Grade, Aldrich Chemlcal Company) was used without further purification. 
P1val1c ac1d

P1valic ac1d. (Reagent Grade, Matheson, Coleman, and Bell) was used without further purification.

\section{Thionyl chloride}

Reagent grade thionyl chloride (Matheson, Coleman, and Bel1) was used without further purification.

\section{Toluene}

Toluene (Reagent Grade, Allied Chemical and Dye Company) was refluxed and distilled from fused sodium through a Vigreaux column. The fraction bolling at $110-111^{\circ}$ was used.

\section{Triphenylmethyl chloride}

Triphenylmethyl. chloride (Eastman White Label, Eastman Kodak Company) was recrystall1zed from petroleum ether in the presence of acetyl chloride. The starting material was a pink-orange color. This material was dissolved in petroleum ether, to whlch was added a few $\mathrm{ml}$. of acetyl chloride. The solution was treated w1th act1vated carbon (Nor1te A). White needles melting at $110-111^{\circ}$ were obtalned after f1ltering and cooling the solution. Tripherylmethyl chloride was also recrystallized from pure petroleum ether in a dry box. 
Preparation of D1pivaloylmethane

Preparation of trimethylacetyl chloride

An ether solution of $600 \mathrm{~g}$. of trimethylacetic ac1d and 845 g. of thionyl chloride was refluxed for 3 hours. The reaction mixture was fractionated through a spinning band column. The fraction bolling below $100^{\circ}$ was discarded. The yleld was $620 \mathrm{~g}$. $(88 \%)$ of pivaloyl chloride which boiled at $105-107^{\circ}$.

\section{Preparation of phenyl pivalate}

A three necked flask contalning $500 \mathrm{~g}$. of phenol, $150 \mathrm{~g}$. of magneslum metal and $500 \mathrm{ml}$. of benzene was f1tted with a stirrer, condenser and addition funnel. The mixture was brought to a reflux temperature. $S 1 x$ hundred and twenty $g$. of pivaloyl chloride and $500 \mathrm{ml}$. of benzene were placed in the addition funnel and added to the refluxing mixture over a two hour period. The solution was then refluxed for a further four and one-half hours. Hydrogen chloride evolution could then no longer be detected. The solution was filtered, d)luted with ether, and washed with $5 \%$ aqueous sodium hydroxide. The ether layer was drled over calclum chloride. Benzene and ether were stripped off through a vigreaux column. The remaining product was distilled through a spinning band column. A yield of $830 \mathrm{~g}$. (90\%) was collected over a temper- 
ature range of $95-97^{\circ}$ at $10-13 \mathrm{~mm}$.

Preparation of 11 thium dipivaloy lmethane

A three-necked flask f1tted w1th stirrer, condenser, and gas inlet was immersed in an acetone-dry 1ce bath. About $1500 \mathrm{ml}$. of anhydrous ammonia was adm1tted at ate to allow only slight reflux. Approximately $30 \mathrm{~g}$. of 11 thium wire (1-2 inch strips) was added over a period of one hour. After adding $0.2 \mathrm{~g}$. of ferric nitrate, the solution was st1rred for $2 \frac{1}{2}$ hours. The st1rring was discont1nued and the acetone-dry 1 ce bath removed. About one 11 ter of ether was added when the mixture reached room temperature. Lithlum am1de was seen as white suspension after the solution stood overnight. The mixture was refluxed for one hour to drive off any remaining ammonia.

A solution of $350 \mathrm{~g}$. of pinacolone in dry ether was added over a $1 \frac{1}{2}$ hour perlod (ether refluxed slowly) to the lithlum am1de suspension. A solution of $350 \mathrm{~g}$. of phenyl trimethylacetate and $200 \mathrm{ml}$. of dry ether was then edded within one-half hour. The mixture was refluxed for 4 ti hours during which time the stirring was continued vigorousiy. The product was poured into 1ce water producing wh1te butter11ke suspension. The solld 11 thlum dip1valoglmethane was f1ltered and washed w1th water. 


\section{Hydrolysis of 11thium dipiveloylmethane}

One hundred gram portions of I1thium diplvaloylmethane were placed in a separatory funnel contalning one liter of ether. Most of the solid remalned undissolved. The suspension was shaked w1th $100 \mathrm{ml}$. portions of $5-10 \%$ aqueous hydrochloric acid until the solid material dissolved and the red color (traces of ferric dipivaloylmethane) disappeared.

The ether solutions from the above hydrolysis were comb1ned. The solvent was removed by dist1llation through a 12 Inch Vigreaux column. The remaining material was passed through spinning band column. A $90 \%$ y1eld of dipivaloylmethane was obtalned. The bolling polnt was $93^{\circ}$ at $20 \mathrm{~mm}$.

\section{Preparation of itetal Chelates}

of D1p1valoylinethane

\section{Preparation of nickel d1p1valoylmethane}

D1p1valoylmethane and nickelous acetate were dissolved in a 50\% ethanol-water solution. The solution was shaked for 30-45 m1nutes. A green flocculent prec1p1tate of n1ckel dipivaloylmethane dihydrate was formed. The precipitate was thoroughiy washed with an ethanol-water solution and then dried under heat lamp which dehydrated the chelate to form a pink solid. Thls solid was sublimed three tines at $150^{\circ}$ at $5 \mathrm{~mm}$. The flrst sublimation was interrupted after an 011 (probably dipt.valoylmethane) was deposited on the condenser. 
A light yellow residue (nickel acetate) remained after the n1ckel chelate sublimed. The nickel chelate ( $85 \%$ yleld) melted at $222-225^{\circ}$.

\section{Preparation of zinc diplvaloylmethane}

The above procedure was followed for the preparation of zinc dip1valoylmethene wh1ch melted at $144_{4}^{\circ}$.

\section{Preparation of copper dip1valoylinethane}

Copper d1p1valoylmethane was prec1p1tated in the same manner as nickel and $z 1 \mathrm{nc}$ diplvaloylmethane. The product was purified by recrystallization from dimethylformamide (melting point $\left.197-198^{\circ}\right)$.

\section{V1sible Absorption Spectra of N1ckel DPM}

V1sible absorption spectra of nickel DPM in benzene and In ejclohexane were determined with Beckman Model DU spectrophotometer and matched $1 \mathrm{~cm}$. s1110a cells. A plot of percent transultance versus wavelength gave amooth curve with a minimum at $534 \mathrm{my}$. The molar extinetion coefficient (f, $534 \mathrm{~m}$ ) of a $5.7 \times 10^{-3}$ molar solution of nickel DPM in benzene was found to be 54 . Plots of $\log \%$ transmisaion versus concentration of nickel DPM in benzene and in eyclohexane gave good stralght lines 1ndicating that nickel DPM follows Beers Law in both solvents over a concentration range 0.01-0.001 moler. 


\section{A1r Oxidation of N1ckel DPM}

Solutions of nickel DPM in varlous solvents were oxidized by allowing them to stand open to the atmosphere. These experiments were conducted by placing the solutions in Erlenmeyer flasks, stoppered and unstoppered, and observing the d1sappearance of the p1nk-v1olet color wh1ch 18 characterist1c of nickel DPM. Phree $10 \mathrm{ml}$. portions of a 0.01 molar solution of nickel DPM In benzene were propared. Sample number one was left unstoppered; sample two was stoppered with an unrolled cork; the third sample was stoppered tightly w1th a lightly greased ground glass plug. The following t1mes were required for the disappearance of the plnk color of semples 1, 2, and 3 respectively: 12 hours, 30 bours, 1nder1n1te. S1m1lar results were obtalned when this exper1ment was repeated using toluene and chlorobenzene solvents. hn attempt was made to oxldize nickel DPM in ejelohexane. The procedure followed was similar to thet described with the solvents above. No disappearance of the nickel DPI color was detected even when the cyelohexane solutions were saturated. with water.

\section{Quant1tat1ve ox1det1on of n1ckel DPM}

An 1 nvest1gation of the quantitstive oxidation of nickel DPU was made. The rates and amounts of oxygen uptake were measured in the gas apparatus described by Boozer, Hammond, 
Ham1lton and $\mathrm{Sen}^{23}$.

Oxidation in chlorobenzene F1ve ml. of $5.6 \times 10^{-2}$ molar solution of nickel DPM in chlorobenzene was placed in the gas apparatus at $70^{\circ}$. The volume of oxygen uptake was followed by observing the level of oll (Convoll 20) in the burettes.

\section{Oxidation in anlsole Attempts were made to oxidize} n1ckel DPM in anisole. P1ve ml. of saturated solution was placed in the gas apparatus over oxygen. About one $\mathrm{ml}$. of oxygen was absorbed over a s1x hour per1od. After 18 hours, the solution was yellow. Th1s solution was placed in a $10 \mathrm{ml}$. slask fitted to a reflux condenser. After refluxing five minutes, the plnk-violet color was observed. The yellow color reappeared when the solution was allowed to stand open to the atmosphere 24 hours. The solvent was distiled, leaving a sol1d whlch appeared to be n1ckel DPM (melting polnt $215-218^{\circ}$ ). No depression of the melting polnt was observed when the solld wes m1xed with authentic nickel DPM.

\section{Oxidation in nitrobenzene The procedure followed in} the oxidation of $\mathrm{nickel}$ DPM in anlsole was repeated using n1 trobenzene as solvent.

Oxidation in cyclohexane Five ml. of $0.01 \mathrm{molar}$ solution of nickel DPM in eyclohexane was placed in the gas

23 Charles E. Boozer G. S. Hammond, Chester E. Ham1lton and Jyotrind1a v. Sen, ‥ Am. Chem. Soc., Z7, 3233 (1955). 
apparatus. No significant anount of oxjgen was absorbed w1thin 2 hours. No color change was noticed after prolonged standing.

\section{In1tiation of cumene oxidation by nickel DPU}

The oxidation of eumene was followed by using the gas apparatus described previously. A typlcal reaction involved 4 ml. of a 0.01 molar nickel DPM-chlorobenzene solution and 2 ml. of cumene.

\section{Study of the products of alr oxidation of nickel DPY}

Ten g. of unsublimed nickel DPM was dissolved in $200 \mathrm{ml}$. of chlorobenzene. This solution was allowed to stand open to the atmosphere fiff three weeks. The color of the solution changed from the pink-violet color to dark green. The solvent was ovaporated, leaving a green crystalline solid wh1ch melted above $285^{\circ}$.

\section{Solub1lity studies Soiub1lity tests were made by} shaking $50 \mathrm{mg}$. samples of the material with $3 \mathrm{ml}$. of several pure solvents. The material dissolved in the following solvents: chloroform, carbon tetrachloride, benzene, petroloum ther and othanol. Recrystallization could not be effected succesarully in any of these. The product could be reprec1pitated from ethanol by adding a fer drope of water. Th1s precip1tate analyzed as follows: C, $39.28 \%$ H, 6.216 . 
Elomental analyo1s The product from the alr oxidation in chlorobenzene was analyzed for chlorine by the procedure outlined by Shiner and Fuson 24 . No chlorine was detected.

Infrared spectra Infrared spectra were measured with

a Perkin-Blmer Model 21 spectrophotometer. These spectra were obtained from nujol mulls and solutions of the material in carbon tetrachloride.

Gas chromatographic separation A benzene solution of the product from the alr oxidation of nickel DPM was separated on a gas phase chromatographlc instrument (Aerograph Model, W1lk1ns Instrument and Research, with a Varian Assoclate graphic recorder). About $1 \mathrm{~g}$. of the solid was dissolved $\ln 2 \mathrm{ml}$. of benzene. Five microliters of this solution was injected Into an asphalt "B" column at $170^{\circ}$. The recorder was set at high speed. The gas phase chromatogram of the above solution was compared to that of a solution of pivalic ac1d in benzene. Peaks occured at corresponding positions on the two graphs. When equal parts of the two solutions were mixed, no now peak was observed. Hydrolysis of oxidation product An ether solution $(0.1 \mathrm{~g}$. of the product of nickel DPM oxidation in $10 \mathrm{ml}$. of diethyl ether) was placed in separatory funnel. Th1s

24 R. L. Shiner and R. C. Fuson, The Systematio Ident1rlcation of Organic Compounds", John wiley and Sons, Ine., New York (19148) p. 55. 
solution was shaken with five $5 \mathrm{ml}$. portions of 0.1 molar aqueous hydrochloric ac1d. The ether layer was dried with anhydrous calclum sulfate. When the ether was evaporated, a solid material (melting point, $25-30^{\circ}$ ) remalned.

The Infrared spectrum of this solid (using sodium chlorlde plates) was taken. Th1s spectrum was 1dentical to that of pivalic ac1a.

A gas phase chromatogram (1nstrument described previously) of the hydrolysis product was obtained. Five microliters of a solution of the solid in ether was put through an Aplezon "C" column at $150^{\circ}$. Two peaks were observed. These peaks were 1dentical w1th those found when an ether solution of pivalic acid was chromatographed.

Preparation of nickel pivalate An authent1c sample of nickel pivalate was prepared as follows: pivalle acid was saturated $w 1$ th $n 1 c k e l$ acetate at $100^{\circ}$ in a round bottomed flask. The flask was further heated and some acet1c ac1d distlled off. On cooling, a green precipltate formed. The prec1p1tate analyzed as follows: C, $39.62 \%$ H, $6.78 \%$.

Reaction of N1ckel DPM with Triphenylmethyl Chloride About $75 \mathrm{ml}$. of cyclohexane was added to a $100 \mathrm{ml}$. round bottomed flask fitted with a reflux condenser and drying tube. Equimolar quantities $(2.7 \mathrm{~g}$. trityl chloride, $4.2 \mathrm{~g}$. niekel DPX) wore added. This solution was refluxed for four hours. A quantitative yield of nickel chloride was isolated. The 


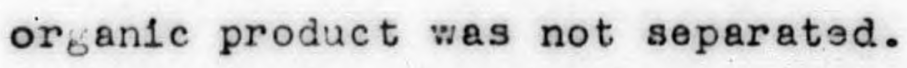

Reactions of N1ckel DPM with Benzoyl Chloride

A solution of $3 \mathrm{~g}$. of nlckel DPM, $1 \mathrm{~g}$. of benzoyl chlorlde, and $75 \mathrm{ml}$. of cyclohexane was placed in a $100 \mathrm{ml}$. round bottomed flask. The flask was fltted with a reflux condenser and drying tube. The solution was refluxed for $2 \frac{1}{2}$ hours. A yellow precipitate was formed. The precipltate was collected, washed with cold cyclohexane, and added to $10 \mathrm{ml}$. of distilled water. Part of the precipitate dissolved in water. The remaining solid was washed with water and then dissolved in methanol. A few drops of water was added. The solid prec1p1tated as white needles (melting point $172-173^{\circ}$ ). Anal. calcd. for $\mathrm{C}_{18} \mathrm{H}_{24} \mathrm{O}_{3}: \mathrm{C}, 74.98 \% ; \mathrm{H}, 8.39 \%$. Found: C, $75.40 \% ; \mathrm{H}, 8.31 \%$.

An infrared spectrum of the product was taken using $0.1 \mathrm{~mm}$. cells with chloroform as the solvent.

\section{Reaction of N1ckel DPM w1th $\rho$-Methoxybenzoyl Chloride}

A round bottomed flask was fitted with a reflux condenser and drying tube. A solution containing $3 \mathrm{~g}$. of nickel DPM and $1.62 \mathrm{~g}$. of $\rho$-methoxybenzoyl chloride in $75 \mathrm{ml}$. of cyclohexane was placed in the flask and refluxed. A yellow precipitate began forming 1mmediately. Refluxing was continued until the color of nickel DPM had disappeared (/4 hours). The yellow 
precipitate was then collected and washed with cold cyclohexane. When placed in water, part of the solld dissolved. The remaining solid was washed with water and then recrystallized in petroleum ether.

The infrared spectrum of the solld was measured using chloroform as the solvent.

Kinetics of the Reaction of N1ckel DPM $\nabla 1$ th Triphenylmethyl Chloride

The reactions were carried out in 100 and $200 \mathrm{ml}$. round bottomed flasks each of which has a side arm with alameter of $1 \mathrm{~cm}$. The flasks were stoppered in most cases. The side arms were fltted with rubber serum caps. The flasks were Immersed in a constant temperature bath, a $12 \times 12$ inch beaker f1llod with mineral oil (Mefford Chemical Company). The oll was heated with a blade type heater which was controlled by an electronic relay (Procieion Scientific Company).

A description of a typical kinetic run follows: A solution contalning $1.1274 \mathrm{~g}$. of triphenylmethyl chloride in cyclohexane was diluted to $50 \mathrm{ml}$. In a volumetric flask. A sample of nickel DPM we1ghing 0.4550 g. was placed in a second volumetric flask and diluted to $50 \mathrm{ml}$. with cyclohexane. The flesks were suspended in the oll bath for 15 minutes. The solutions were tben poured into the reaction flask, flushed w1th nitrogen, and stoppered with a standard taper plug. 
Samplos were extracted through the side arm wh th $5 \mathrm{ml}$. syringe fitted with a hypodermic needle. Each sample was Immediately transferred to a centrifuge tube, cooled in an 1ce bath, and centrifuged for five minutes. The samplo was then transferred to a $1 \mathrm{~cm}$. Bllica cell which was placed in the spectrophotometer for the determination of the remaining nickel DPM.

\section{Runs with nickel chloride added}

Anhydrous rilckel chloride was prepared by bubbling anhydrous hydrogen chloride through a 0.01 molar solution of n1ckel DPM in cyclohexane. The nlckel chloride was washed several times with dry cyclohexane. Th1s product was added to the reaction flask and the kinetic run described proviously was reperated.

\section{Runs with dip1valoy methane added}

A typical kinetic run wa made with a oolution which contelned one $\mathrm{ml}$. of dipivaloylmethene(DPM).

\section{Cataiyt1c effects of aluminum chloride}

An attempt was made to make eyclohexane solution of trifgl chloride-eluminum chloride complex similar to those described by Brown and coworkers ${ }^{25}$. A solution of $0.5637 \mathrm{~g}$.

$25 \mathrm{H}$. C. Brown and F. R. Hensen, I. Am. Chem. Soc., $\underline{80}$ 2291 (1958). 
of trityl chloride $(0.004$ moles) was placed in the reaction flask with an equimolar amount of aluminum chloride. A stirring bar was placed in the flask to permit magnetic stirring. The solution was heated to $50^{\circ}$ and stirred vigorously. A yellow-orange color appeared, but only part of the aluminum chloride dissolved.

\section{Kinetics of the Reaction of N1ckel DPM with Benzoyl Chloride}

A stock solution of benzoyl chloride was prepared by dissolving $2.4690 \mathrm{~g}$. of benzoyl chloride in cyclohexane and diluting to $50 \mathrm{ml}$.

A standard nickel DPM solution ( 0.24 molar) was prepared. Fifty ml. of the nickel DPM solution was placed in the reaction vessel. Ten ml. of the benzoyl chloride solution was diluted to the mark on a $50 \mathrm{ml}$. volumetric flask. After beling thermally gquilibrated in the bath, the solutions were mixed. Samples were extracted and snalyzed as described previously for the kinetics of the triphenylmethyl (trityl) chloride-nickel DPM reaction.

The rate of benzoylation was followed in the absence of oxygen. The standard solutions of benzoyl chloride and nickel DPM were pipetted into the reaction flask. The flask was fitted with a gas inlet tube which contained a tapered stopcock. The tube was attached to degassing apparatus. This 
apparatus consisted of a bulb fltted with stopeocks for a vacuum line and a nitrogen inlet. After freezing the solution In a dry 1ce-1sopropanol mixture, the system was degassed three times. N1trogen was admitted unt1l the pressure inside the flask was slightly below atmospheric pressure. After the solution melted, 1t was pleced in the constant temperature bath. The rate of reaction was followed as before.

\section{Runs w1th nickel chloride added}

The procedure followed for the study of the catalytic effect of nickel chloride in the trityl chloride-nickel DPM reaction was repeated for tne benzoylation reaction.

\section{Runs w1th DPM added}

The study of the effect of DPM on the rate of bensoylation was mede. The procedure described for determialng the effect of DPM in the tritylation of nickel DPM wa reperted.

\section{Runs w1th water udded}

A typlcal rate run was made in which the eyclohexane was presaturated w1th water. The saturation wa accomplished by shaking a cyclohexane-water mixture in a stoppered Erlenmeyer flask. The cyclohexane was plpetted from the m1xture. 
Catalyt1c offect of aluminum chloride

The aluminum chloride catalysis was investigated following the procedure outlined for the study of tritylation of nickel DPM.

\section{Catalyt1c effect of the product from the oxidation of nickel}

\section{DPY in benzene}

The oxidation product $(0.1 \mathrm{~g}$.$) was added to a reaction$ flask during a typlcal kinetic run.

\section{K1net1cs of the Reaction of N1ckel DPM with $p$-Methoxybenzoyl Chloride}

A standar'a solution $(0.215$ molar) of anisoyl chloride was prepared by dissolving $3.6715 \mathrm{~g}$. In $100 \mathrm{ml}$. of cyclohexane. Ten ml. of this solution was diluted to $50 \mathrm{ml}$. Thls was added to $50 \mathrm{ml}$. of the nickel DPM solution, both having been prebeated to the desired temperature. Samples were extracted at various intervals and analyzed. The rate or the methoxybenzoylation of nickel DPM was followed in degassed system similar to that described for the benzoylation.

\section{Catelys studies}

The catalytic effects of the following reagents in the methoxybenzoylation of nickel DPM were invest1gated: anhydrous nickel chloride, diplvaloylmethane, water, anhydrous aluminum chloride and the product of nlckel DPM oxidation. 
The experimental procedures followed during these studies were 1dentical to those described for the study of the catalytic effects of these reagents in the tritylation and benzoylation.

\section{Kinetics of the $\rho$-Chlorobenzoylation} of N1ckel DPM

Fifty ml. of the standard nickel DPM solution were m1xed with $50 \mathrm{ml}$. of a $p$-chlorobenzoyl chlorlde-cyclohexane solution ( $0.045 \mathrm{molar})$. The kinetics were followed in the presence and absence of oxygen. The procedures were similar to those previously dascribed. 


\section{RESULTS AND DIGL_SEION}

\section{Prel1m1nary Remarks}

Nickel dipivaloylmethide was used in these studies for several reasons. It 1 s aery stable chelate which is easily aublimed in vacuo. N1ckel DPM is moderately soluble in most organic solvents. Preliminary studies indicated that the moderate rates of alkylation and acylation of nickel DPM, compared to other metal chelates, are favorable for formal k1netic studies. The products obtalned from alkylations and acylations of the nickel chelate are typlcal of those from most metal chelates.

N1ckel DPM offers several possible methods of analysis. The chelate itself as well as the nickel chloride produced In the reaction have characteristic absorptions in the viaible range. Thls, plus the ease of deternination of nickel by chemical methods, made nickel DPM seem very attractive as a substrate for alkglations and acylations.

Triphenylmethyl chloride and benzoyl chloride were selected as the reagents because the products of tritylation and benzoylation are sollds which were seemingly easily characterized. The desire to determine subst1tuent effects necessitated the use of substituted benzoyl halldes. 


\section{Prosontation and D1 scuselon of Data}

The rates of recetion of nickel DPM with trityl ohloride and with $\rho-\mathrm{H}, \rho-\mathrm{OCH}_{3}, \rho-\mathrm{Cl}$, and $\rho-\mathrm{HO}_{2}$ benzogl ohlorides wore studied at three temperatures $\left(30^{\circ}, 50^{\circ}\right.$, and $\left.60^{\circ}\right)$. Cyelohoxane was found to be atisfactory olvent. S1nee earlier Investigations of the reactivity of metal chelates of -diketones 26 wore made in aromatie solvents, benzone was originally chosen es the solvent in these kinotio studies. But, 1t was found that the color of a nlckel DPM-benzene solution turned from pinir-violet to green after this solution was allowed to stand open to the atmosphere. Th1s phenomenon was origlnally explained as the hydration of nlekel DPU to tho ostahodral dihydrate. The same observations were mado when the experiment was ropeated with dry benzene, toluene, and xylone. The fact that the rate of change of the color was fastest in vory loosely atoppered flasks showa that the substance which caused this offect was an atmospheric conot1tuont, 11 ther water or oxygen. Since the atmoaphorically catalysed phenomenon did not oecur whon ejelohexano was used as solvent, the jatter was chosen as the solvont for the kinot1e atudies.

26. S. Hammond and D. R. Nonhobel, Unpubliabod atudies, Iore state Colloge, Amos, Iowe (1958), trosont Addrose, G. S: Hanmond, Chomletry Dopartmont, Callfornla Inst1 tute of Teohnologs, Pasadona, Cellfornia. 


\section{A1x oxidation of n1ekel DPM}

The effect ef an atmospher1c subetituent on a benzenenickel DPM solution was found to be an alr oxidation of n1ckel DPM. N1okel DPM is rapidly oxidised in benzene and chlorobenzene. The uptake or oxggen by a nickel DFI-ehlorobenzene solution 1s shown in Figure 1. There is an inhibition period which seeme to be due to an impurity in nickel DPM. The Inhibition period decreased with continued purification of the chelate. Unsublimed niekel DPU has a vary long Inhibition period.

More than two moles of oxygen are absorbed per mole of nickel DPM. This uninitiated oxidation seoms to take place only in various aromatic solvents.

No oxidation occurs in eyclohexane. Under the conditione of these studies andsole-niekel DPM and n1 trobenzene-nickel DPE solutions undergo the color changes observed in the oxtdation, but no appreciable axygen absorption 1s observed. The original color of nickel DPM 1s regenerated when these colutione are refluxed for five minutes. After revereing this process suveral times, nickel DPM can be recovered. Apparentif oxygen complexes or complexes of nickel DPM with these solvents are formed.

The known products of the alr oxidation of nickel DPM in cyelohexane are p1valle acid, and nlekel pivalate. A comparison of the vapor phase chromatogram of a benzene 


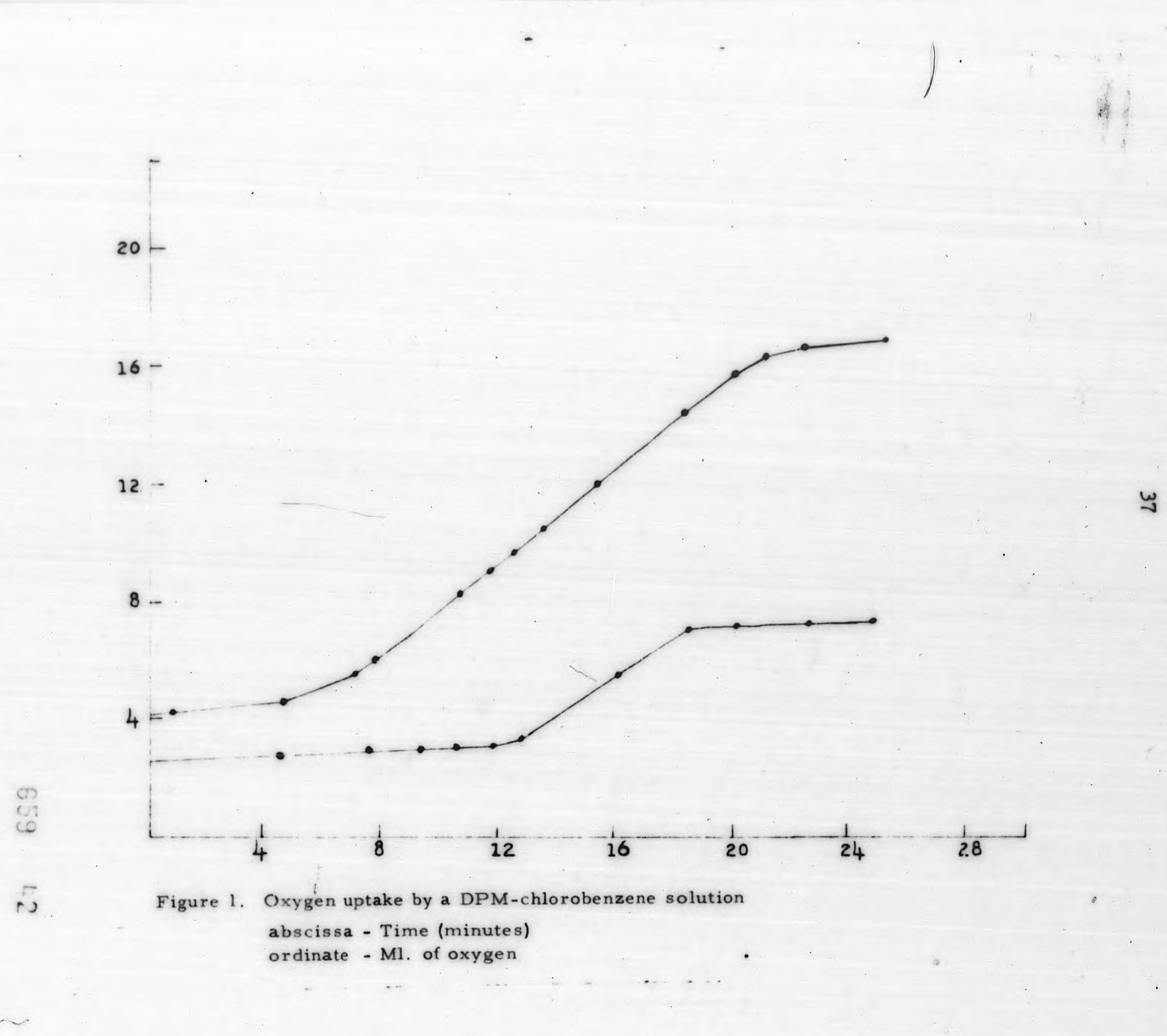


solution of the oxidation product, a pivalic ac1d-benzene solution, and a mixture of these is ahown in Figure 2. Pivalic acid could be detected only with a very concentrated solution of the oxidation product.

About 0.1 g. of the solld product was hydrolyzed with aqueous hydrochloric ac1d. The only organic product found was pivalic acid. The yield of pivalic acid is much too high to have been there all the time. The vapor phase chromatogram of the hydrolysis product compared to that of authent1c pivalic acid is shown in Figure 3. These results plus infrared spectra and $\mathrm{C}, \mathrm{H}$, analysis indicate that the solid product of nickel DPU oxidation 18 nickel pivalate dihydrate. No chlorino was detected in en elemental analysis. The oxidation of the solvent does not occur under the conditions of the reaction.

The analysis of the product of the oxidation of nickel DPU 1 s consistent with the following stolchiometry. $\mathrm{N} 1(\mathrm{DPM})_{2}+4 \mathrm{O}_{2} \rightarrow\left(\mathrm{CH}_{3}\right)_{3}-\mathrm{C}-\mathrm{P}-\mathrm{CH}+\mathrm{N1}\left(\mathrm{CH}_{3}\right)_{3} \mathrm{CC}-\mathrm{C}{ }_{2}+2 \mathrm{CO}_{2}$

No evidence for the production of $\mathrm{CO}_{2}$ was found. The amall amount of pivalle aald whlch was 1solated indicates that equimolar amounts of nickel pivalate and pivalic acid are formed.

The nocessity of an aromatic solvent for the oxidation of nlokel DPM seoms to 1ndicate that an intermediate 1s formed 


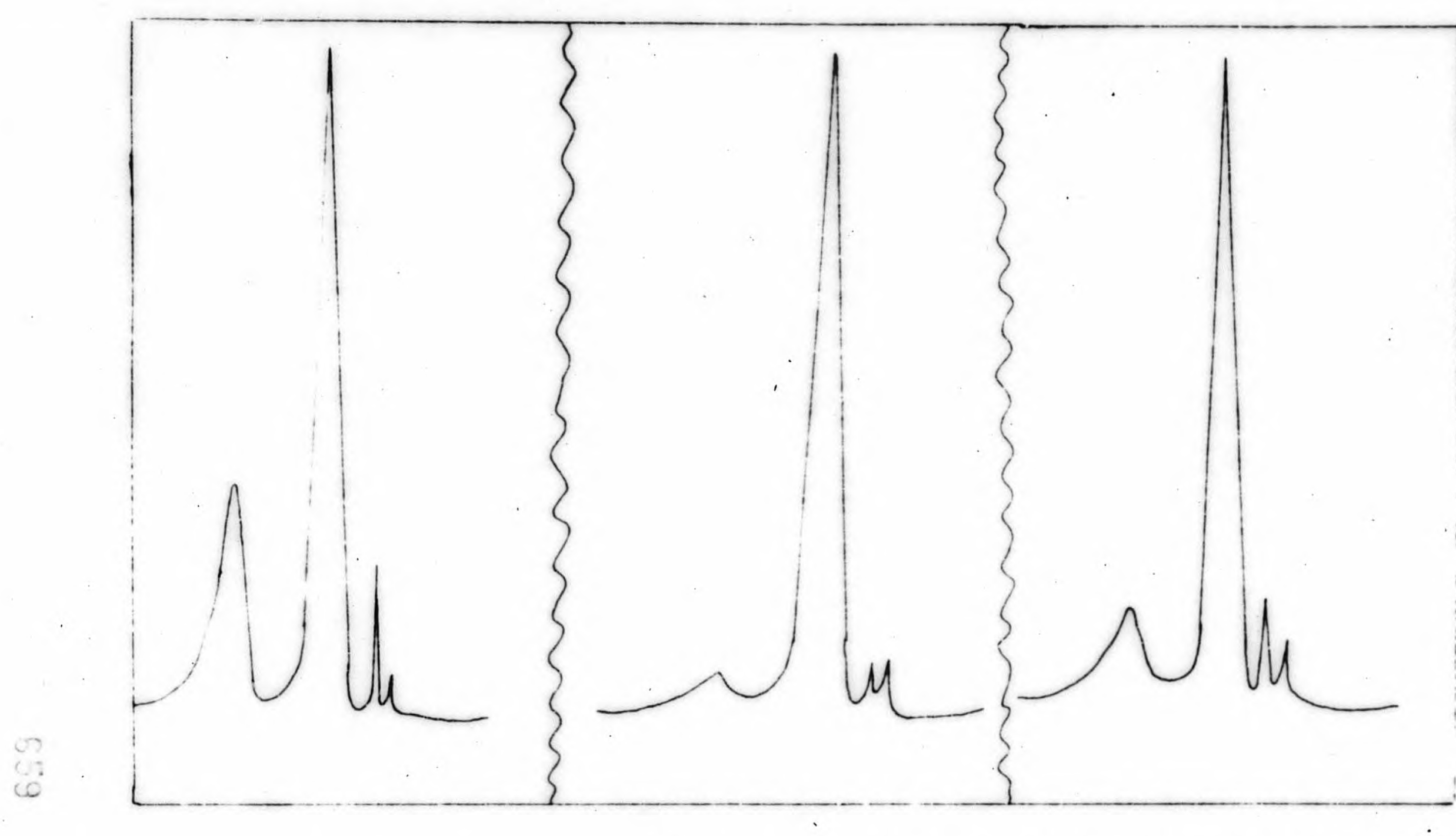

Figure 2. Gas phase chromatogram of product of oxidation of nickel DPM compared to that of Authentic Pivalic Acid. 


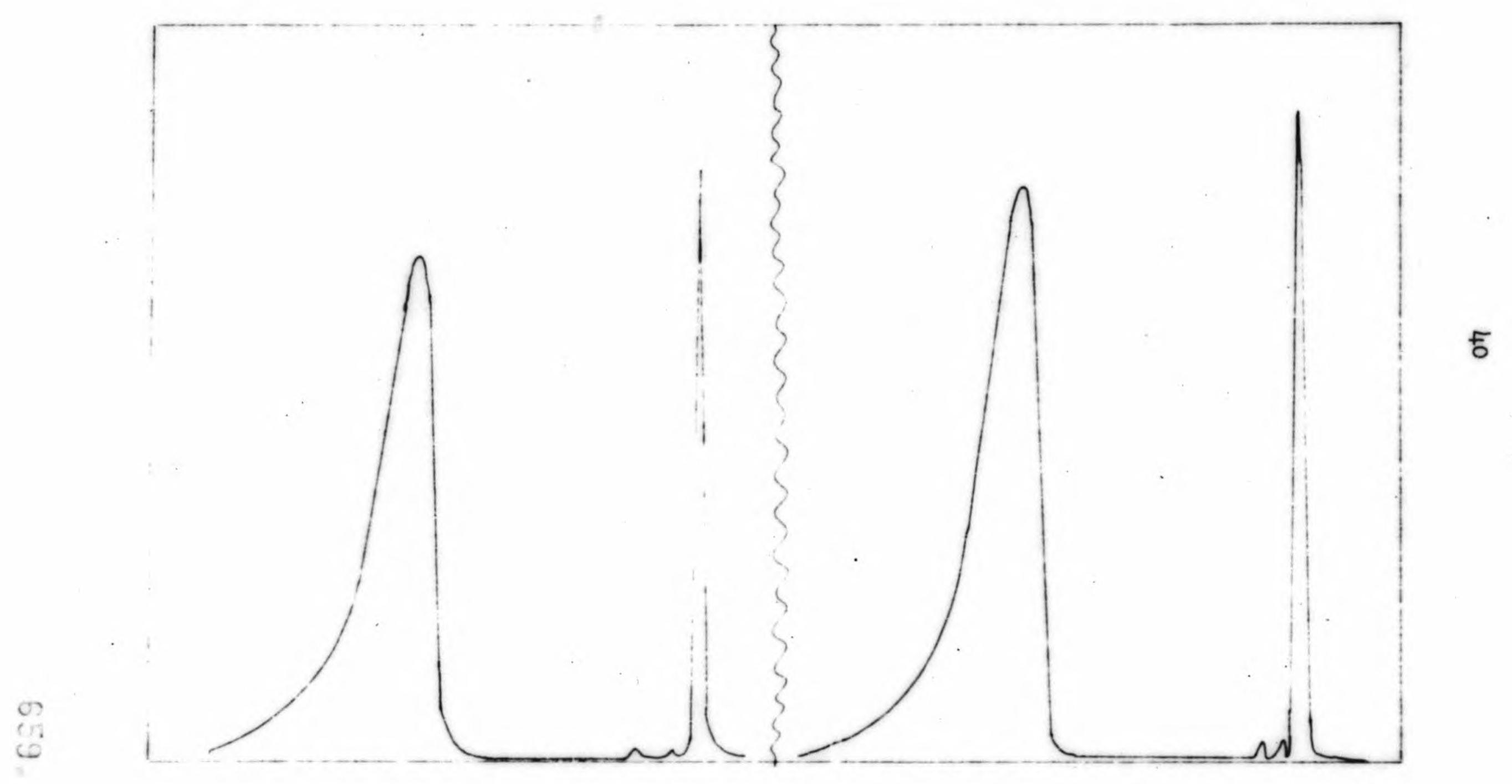

i

Figure 3. Gas phase chromatograms of hydrolysis product of nickel pivalate and authentic pivalic acid. 
whlch 1s stablilized to some extent by an electron rich system.

\section{Intitiation of cumene oxidation br nickel DPI}

The Initiation of the oxidation of cumene by nickel DPM 1s 1liustrated In F1gure 4. Aftor an Inhibition period of four hours, cumene is oxidized at a rate similar to that whon cumene is In1t1ated with azo-b1sisobutyronitrile.

\section{Products and tolohiometry of tritylation and acrlation of}

\section{nlekel DPX}

The organle product of the reaction of tritjl chloride w1th niokel DPU in ejclohexane has not been rigorously 1dentified. The spectrum of this product is compatible to that for an enol ether. The difficulty in 1aolating the pure material plus the 1solation of large amounte of triphenglcarbinol seous to Indicate that 0-tritylation has occurred. The products of acylations of nickel DPU are the triretones. The 1dentification of these products was based primarily on thoir spectra and elemental analysis. Infrared spectra of the products of benzoylation and -methoxjbenzoylation of nickel DPM are show in F1gure 5. The spectrum of the product of $P$-chlorobenzoylation 1 s very sialler to those shown.

The stolchlometry of the tritylation is two moles of trityl chloride per mole of nickel DPU. Th1s was confirmed In several kinetic runs in which an excese of nickel DFu was 
42

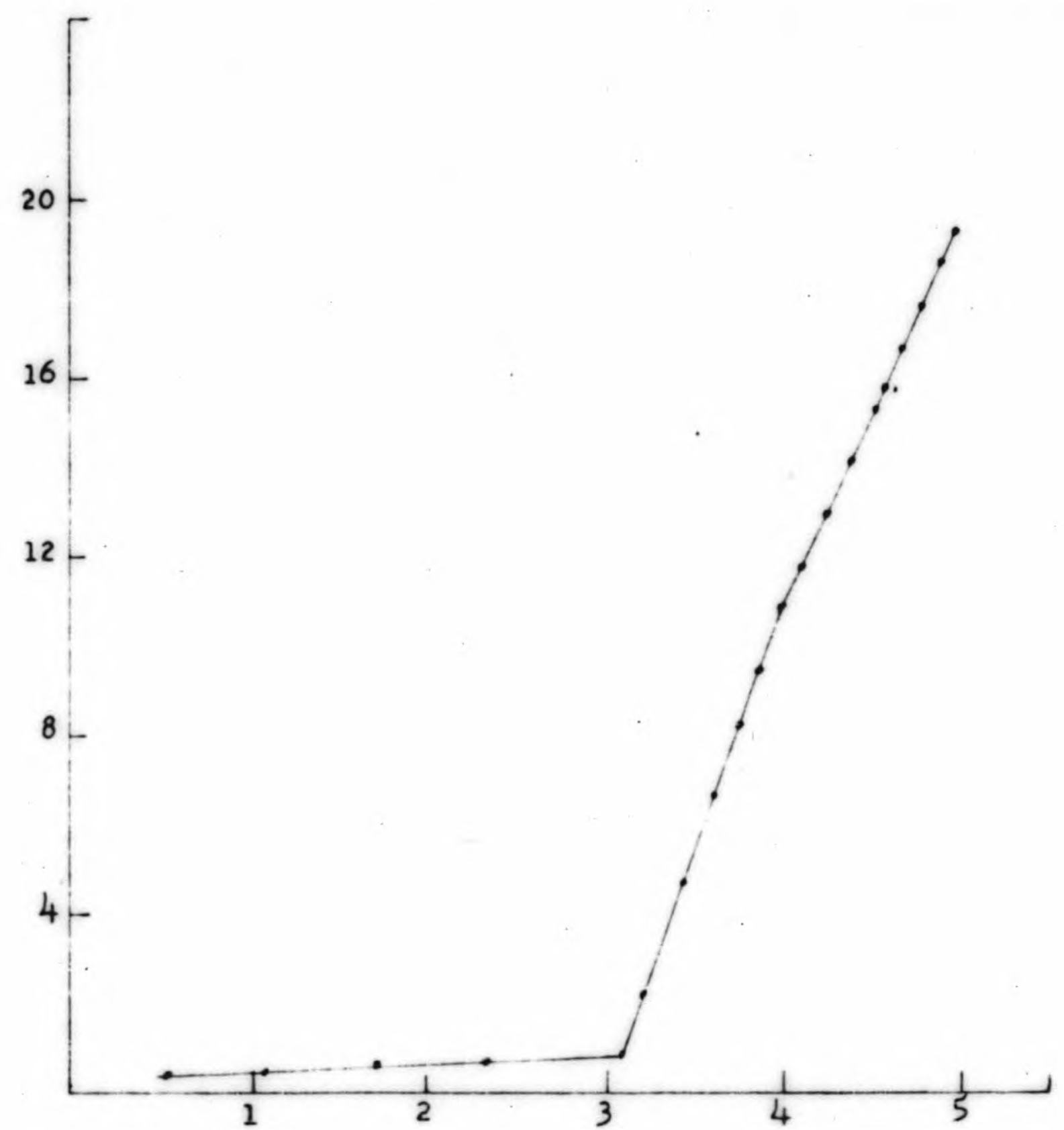

Figure 4. Initiation of cumene oxidation by $\mathrm{Ni}(\mathrm{DPM})_{2}$

abscissa - Time (minutes)

ordinate - Ml. of oxygen 

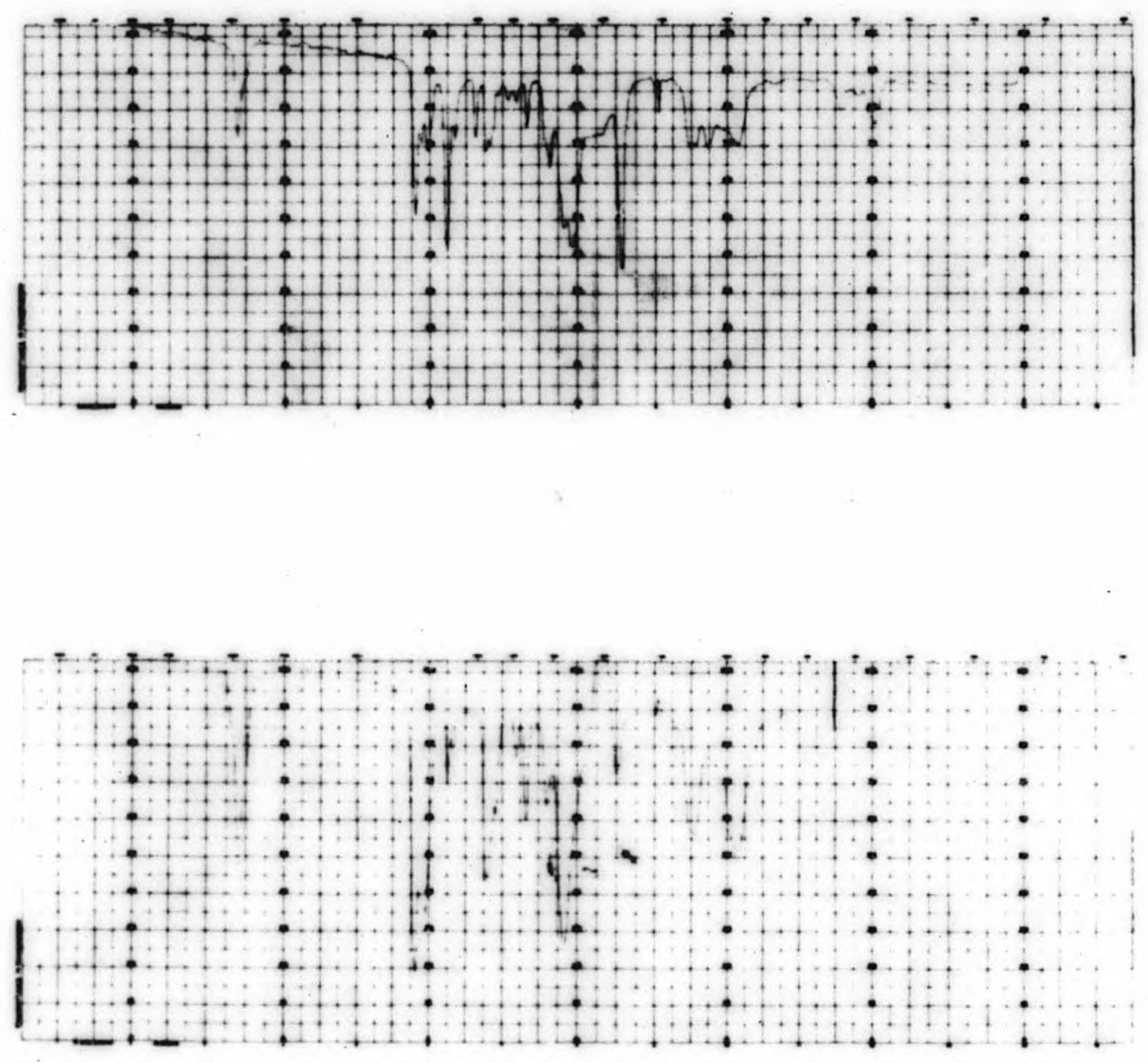

Figure 5. Infrared spectra of product of reaction of $\mathrm{Ni}(D P M)_{2}$ with -chlorobenzoyl chloride (top); benzoylchloride (bottom). 
44

used. The rate of the reaction becaee increasingly slow as the concentration of the reagents reached the value which corresponded to the completion of the reaction as predicted by the 2-1 atolchlometry.

\section{Kineties of tritylation of nickel DPM}

The rate of tritylation at $50^{\circ}$ was found to be second order as described by Equation (1).

$$
\text { (1) rate }=\mathrm{k}_{2}\left[\mathrm{~N} 1(\mathrm{DPM})_{2}\right]\left[\mathrm{C}_{6} \mathrm{H}_{5} \mathrm{COC} 1\right]
$$

4 plot of $\log \frac{b(a-x)}{a(b-2 x)}$, versus time 18 shown in Figure 6. Equation(2) was used to calculate the rate constant from the slope of the best straight line through the pointe.

$$
\text { (2) } k t=\frac{2.303}{(2 a-b)} \log \frac{b(a-x)}{a(b-2 z)}
$$

The rate is unchanged when snhydrous nickel chloride 1s present at the start of the reaction. More evidence that the reaction is not autecatalyzed by nickel chloride was realized when the second order plots of runs, which involved different inftial concentrations, coincided at points where rospective concentrations became equal.

The tritylation is not catalyzed by the addition of DPM.

The rate could not be followed quantitatively when anhydrous aluminum chloride was added because the coloration produced by the added reagent interfered with the spectro- 


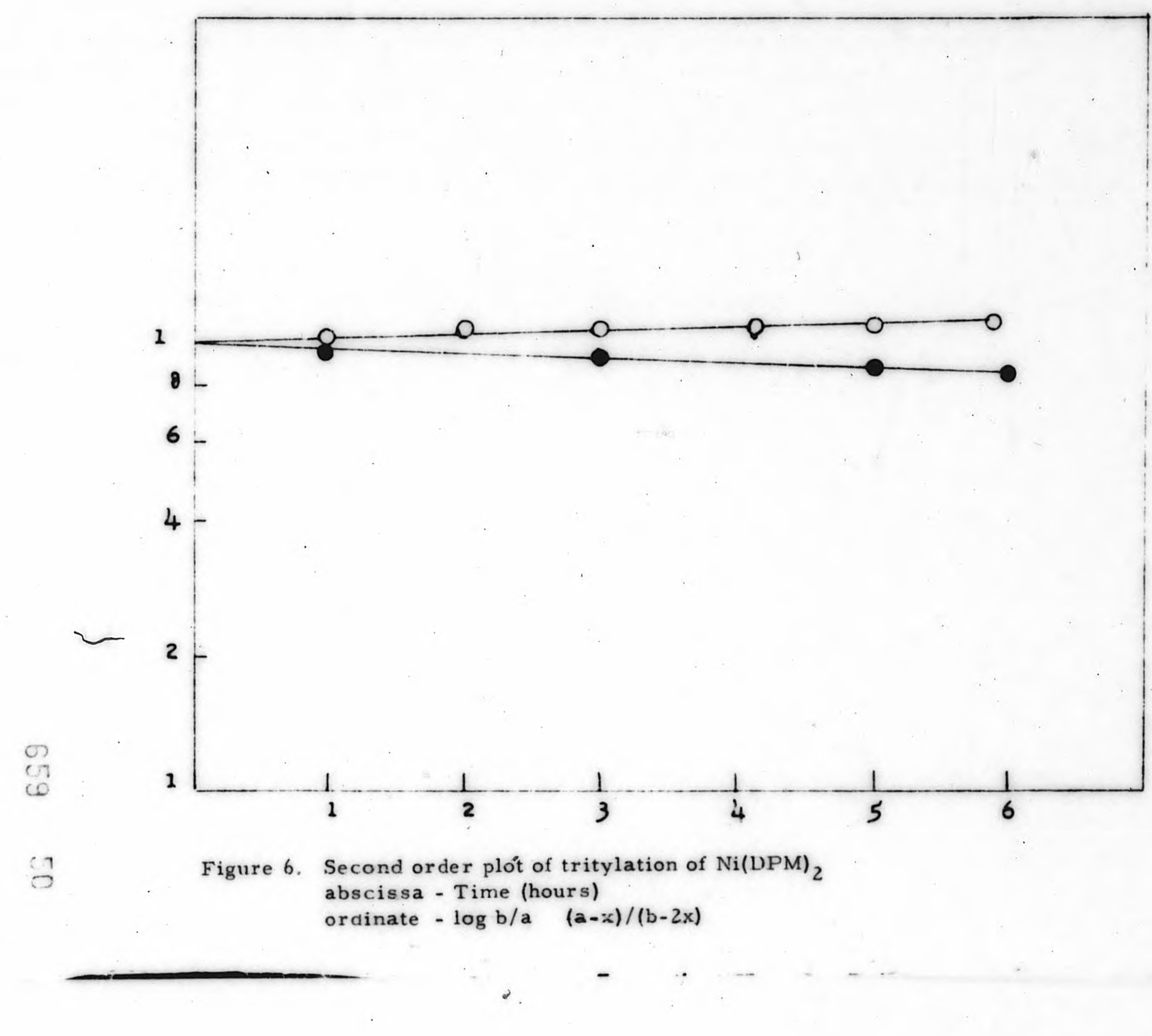


photometric determination of nickel DPU. Qualitative comparison of runs $w 1$ th and w1 thout aluminum chloride indicate that the reaction is about 100 times faster when aluminum chloride 1s added.

The studies of the kinetics of tritylation were carried out in a flask fitted with a condenser and drying tube. When the reaction was attempted in a stoppored flask, the rate slowed down. When the reaction vessel was flushed with n1trogen 1mmediately after the reagents were adcled, no reaction was observed. Th1s of fact $\mathbf{w 1 1}$ be discuesed further when the oxygen effects on the acylations of nickel DPM are described.

\section{Kinetics of the benzoylation of nickel DPM}

The rates of reaction of nickel DPM with benzoyl chloride were investigated at $50^{\circ}$ and $60^{\circ}$. The reaction followed a second order rate law as described by Equation(1). Equation(2) was used to calculate rate constants at each point. The rate constants corresponding to first order dependence on benzogl chloride were calculated using Equation(3).

$$
\text { (3) } k=\frac{2 \cdot 303}{2 t} \log \frac{b}{b-2 x}
$$

$b=$ original concentration of benzoyl chloride (moles/liter) $x=$ amount of nickel DPM reacted (moles/liter) 
The results of these ealculations are shown in Tables 4-8.

The second order rate constant for the benzoylation of n1ckel DPX at $50^{\circ}$ 1s $.019^{\circ} .002$ (11 ter-mole $0^{-1}-\min ^{-1}$ ). When the reaction vessels were flushed with nitrogen and oxggen respectively, the oxygen rich reaction showed a much higher initial rate.

At $60^{\circ}$, the second order rate constant (Table 6) is $.057 \$ .002$ (11ter-mole $\theta^{-1}-\mathrm{m}^{-1} \mathrm{n}^{-1}$ ). The rate. 1s very sensitive to the purity of the benzoyl chloride used. After the standard solution was stored in a stoppered volumetric rlask for a week, the rate of reaction of thls sample was about twice that for the freshly distilled benzoyl chloride. If reagent grade benzoyl chloride is used without furthor purification, the rate is about 10-15 times faster than that observed with the freshly distilled reagent (Table 8 ).

The benzoylation is obviously catalyzed by 1mpurities originally present in the benzoyl chloride and also by materials which are formed in the pure reagent. The most logical cholce seems to be benzolc ac1d.

The rate of berzoylation is increased tenfold when aluminum chloride is added to the reaction. No catalytio effects were observed with nickel chloride or dipivaloglmethide.

N1ckel piralate dihydrate increases the reaction rate very slightly (Table 7). Anhydrous n1ckel p1valate is 
Table 4. Rate of benzoylation of nickel DPI at $50^{\circ}$

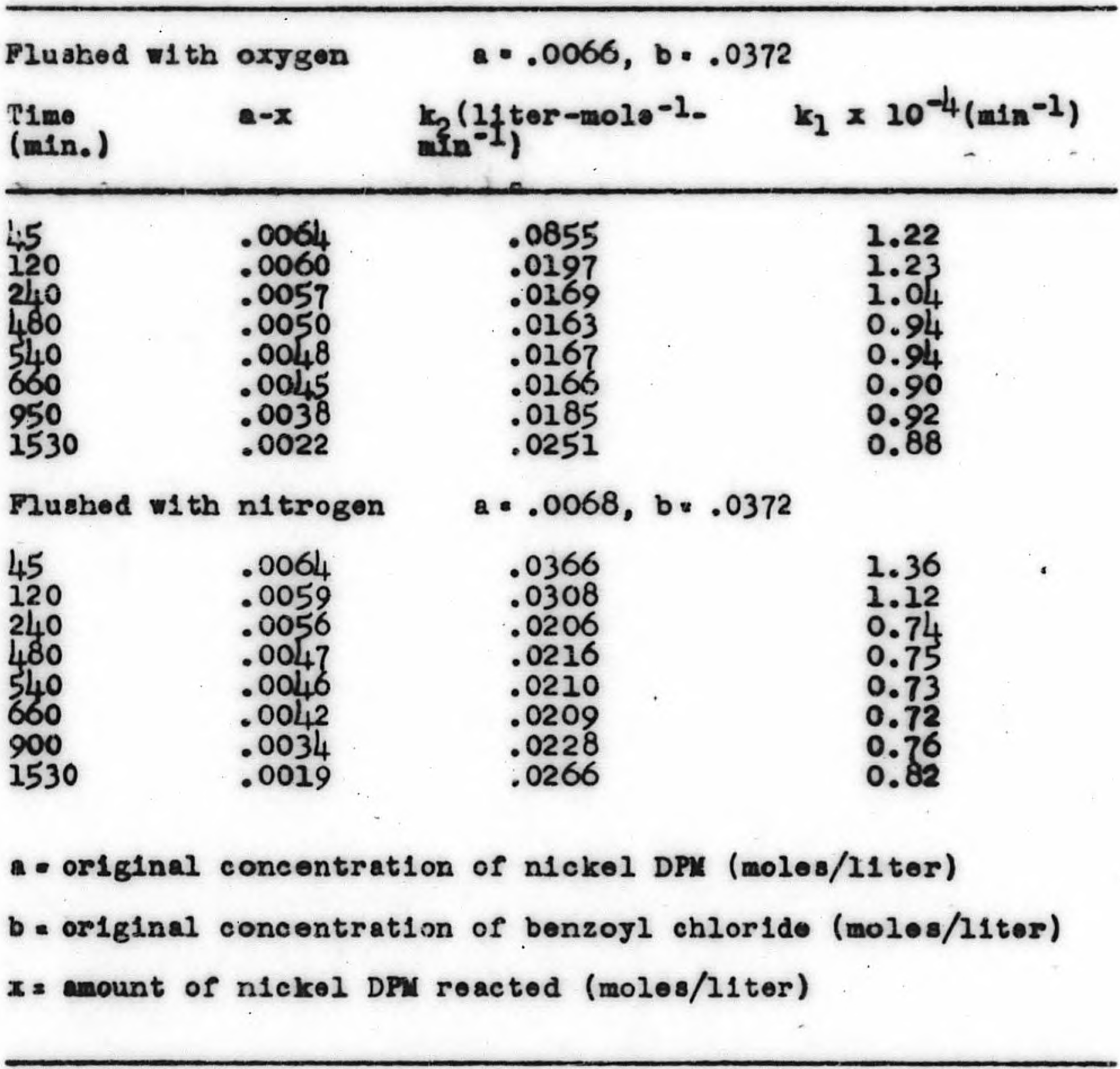

probably much more soluble than tho dinjdrate in cjeloherano. The sormer would probably cataljze the reaction to a greater extent. 
Table 5. Rates of benzoylation of nickel DPM at $60^{\circ}$

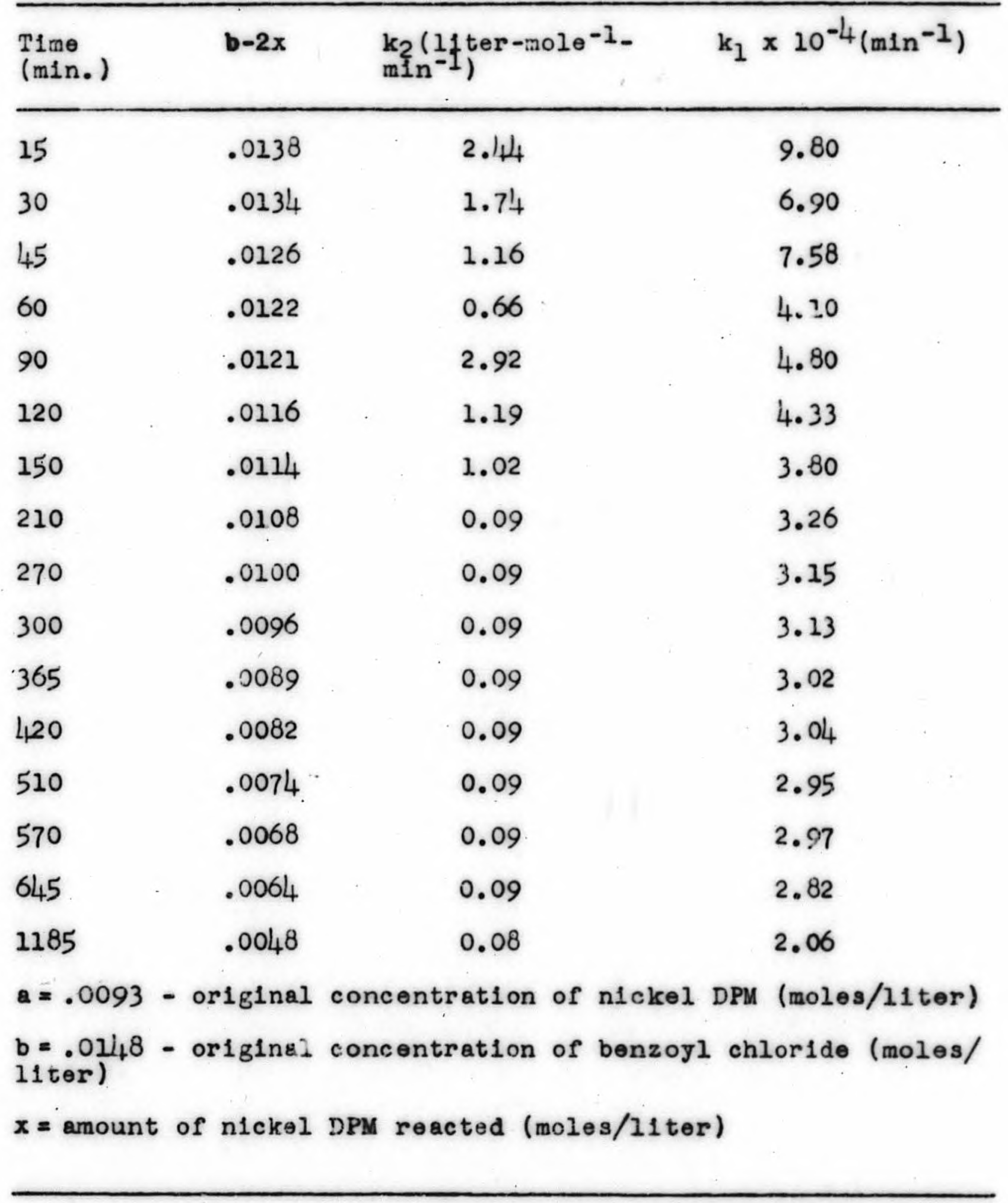


Table 6. Rate of benzoylation of nicikel DPM at $60^{\circ}$

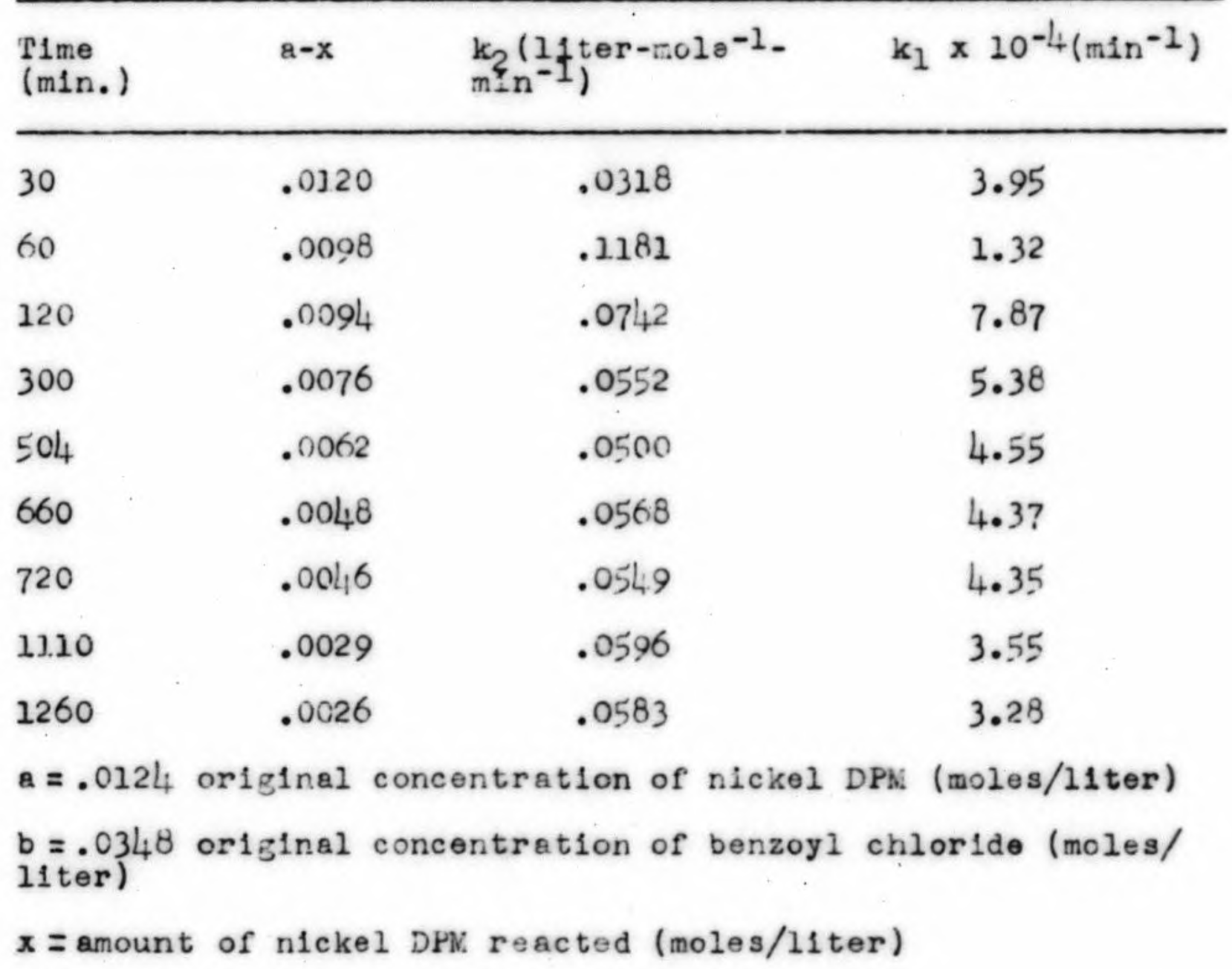

Kinet1cs of the reactions of nickel DPM w1th substituted benzoyl chlor1des

Second order kinetics were found to describe the rates of $p$-methoxybenzoylation and $p$-chlorobenzoylation of nickel DPM. Typical calculated rate constants are shown in Tables 9-11. Difficulties in determining the rate law of these reactions were overcome only after the reactions were carried out in thoroughly degassed systems. F1gure 7 shows a second 
Table 7. Rate of benzoylation of nickel DPM at $60^{\circ}$

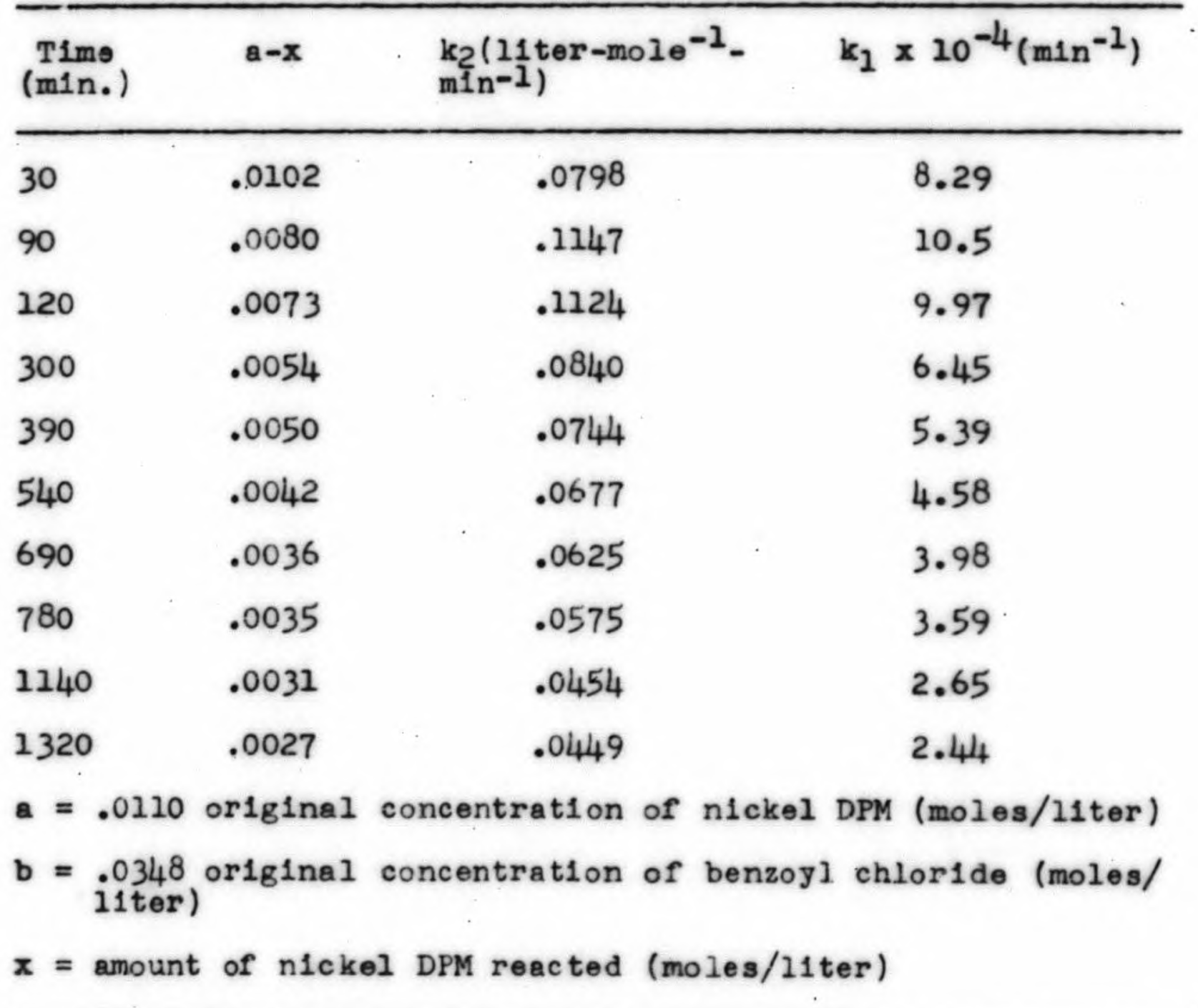

order plot and a first order plot (f1rst order with respect to $\left.\rho-\mathrm{CH}_{3}-\mathrm{O}-\mathrm{C}_{6} \mathrm{H}_{5} \mathrm{COCl}\right)$. These plots indicate a better f1t to a first order rate law. A second order rate law was definitely demonstrated in runs in which the system was degassed (Table 10).

The purities of these acylating agents were determined by potentometric titrations of acyl hallde-methanol mixtures w1th aqueous sodium hydroxide. Figure 8 shows the results of 
Table 8. Rate of benzoylation of nickel DPM at $60^{\circ}$

\begin{tabular}{|c|c|c|c|}
\hline $\begin{array}{l}\text { Time } \\
(\min .)\end{array}$ & $a-x$ & $\begin{array}{l}\mathrm{k}_{2}\left(1 \frac{1}{1} \text { ter-mole }\right. \\
\left.\mathrm{m}_{\mathrm{n}}-1\right)\end{array}$ & $k_{1} \times 10^{-L}\left(\mathrm{~m}^{-1} \mathrm{n}^{-1}\right)$ \\
\hline 10 & .0074 & .440 & 3.1 .3 \\
\hline 25 & .0070 & .270 & 2.03 \\
\hline 35 & .0067 & .265 & 1.95 \\
\hline 60 & .0062 & .221 & 1.57 \\
\hline 90 & .0054 & .233 & 1.54 \\
\hline 120 & .004 .5 & .268 & 1.62 \\
\hline 160 & .0034 & .324 & 1.70 \\
\hline 195 & .0032 & .296 & 1.49 \\
\hline 225 & .0026 & .327 & $1.1 ; 9$ \\
\hline \multirow{2}{*}{\multicolumn{4}{|c|}{$\begin{array}{l}a=.0082 \text { orlginal concentration of nickel DPM (moles/liter) } \\
b=.0227 \text { orleinal concentration of benzoyl chloride (moles/ } \\
11 \text { ter) }\end{array}$}} \\
\hline & & & \\
\hline \multicolumn{4}{|c|}{$x=$ amount of nickel DPM reacted (moles/11ter) } \\
\hline
\end{tabular}

typical titrations. The fact that no break was found in the vertical portion of the titration curves seemed to indicate the absence of detectable amounts of carboxyl1c ac1d. Therefore, an1soyl chloride and $p$-chlorobenzoyl chloride were used in most of the runs without further purification. A few reactions were followed using redistilled anlsoyl. chlor1de. The second order rate constants for those reactions were six times slower than those in which the commercial 
Table 9. Rate of $\varphi$-methoxybenzoylation of nickel DPM at $60^{\circ}$

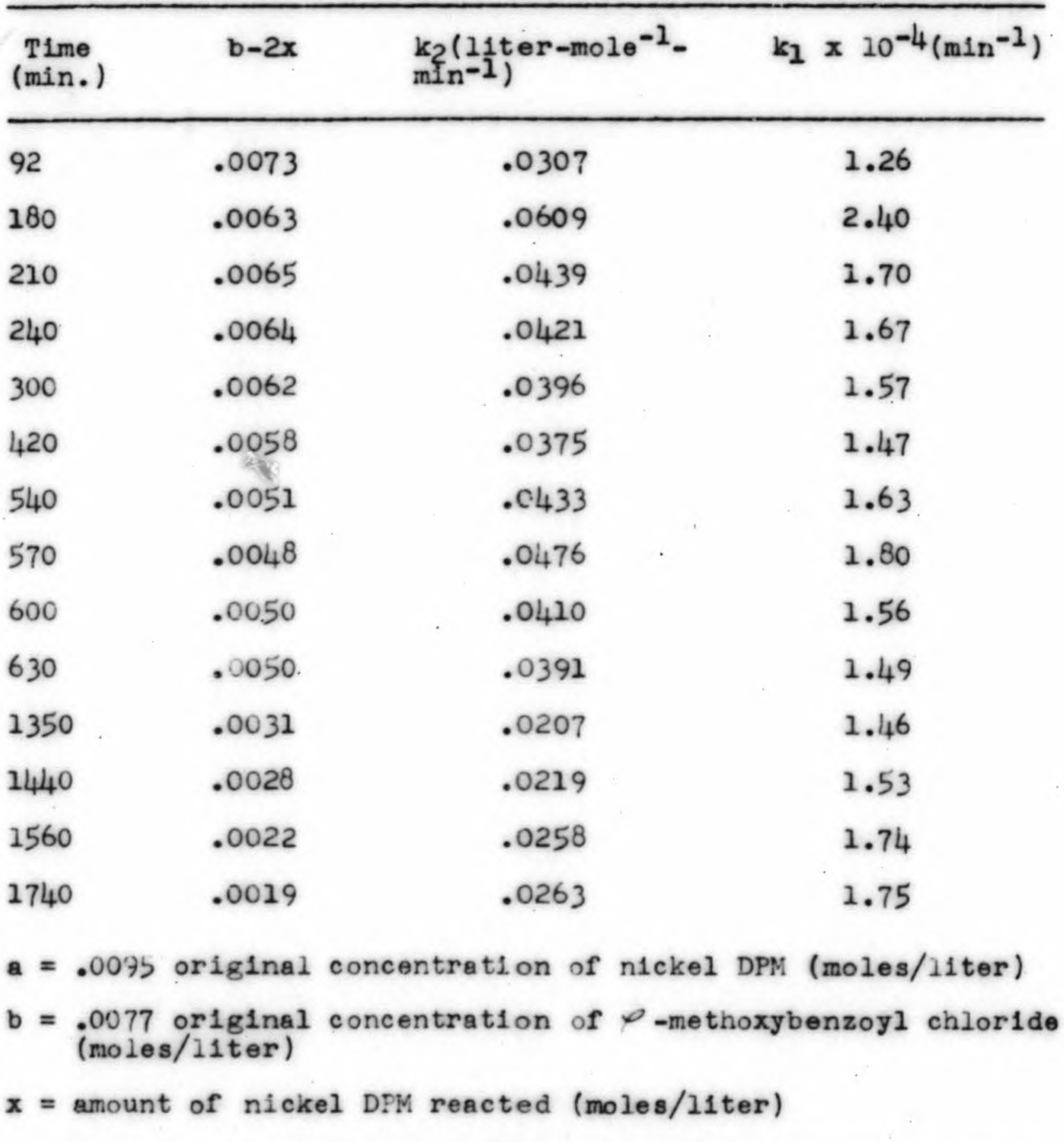

reagent was used w1thout furtier purification (Table 9). The rate of benzoylation snd $P$-methoxybenzoylation has been found to be very similar in most cases. Since the rates 


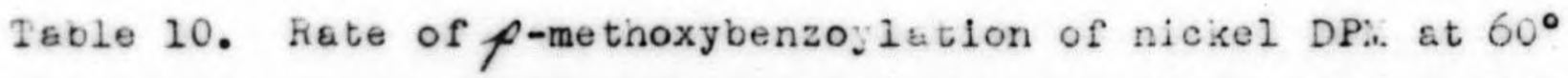



of benzoylation and p-methoxybenzoylation of nickel DPN are known to be enhanced by an impurity in the acylating agents, and, furthermore, since the catalysis of benzoylation by 
Table 11. Pate of p-chlorobenzoylation of nlckel DPM at $60^{\circ}$

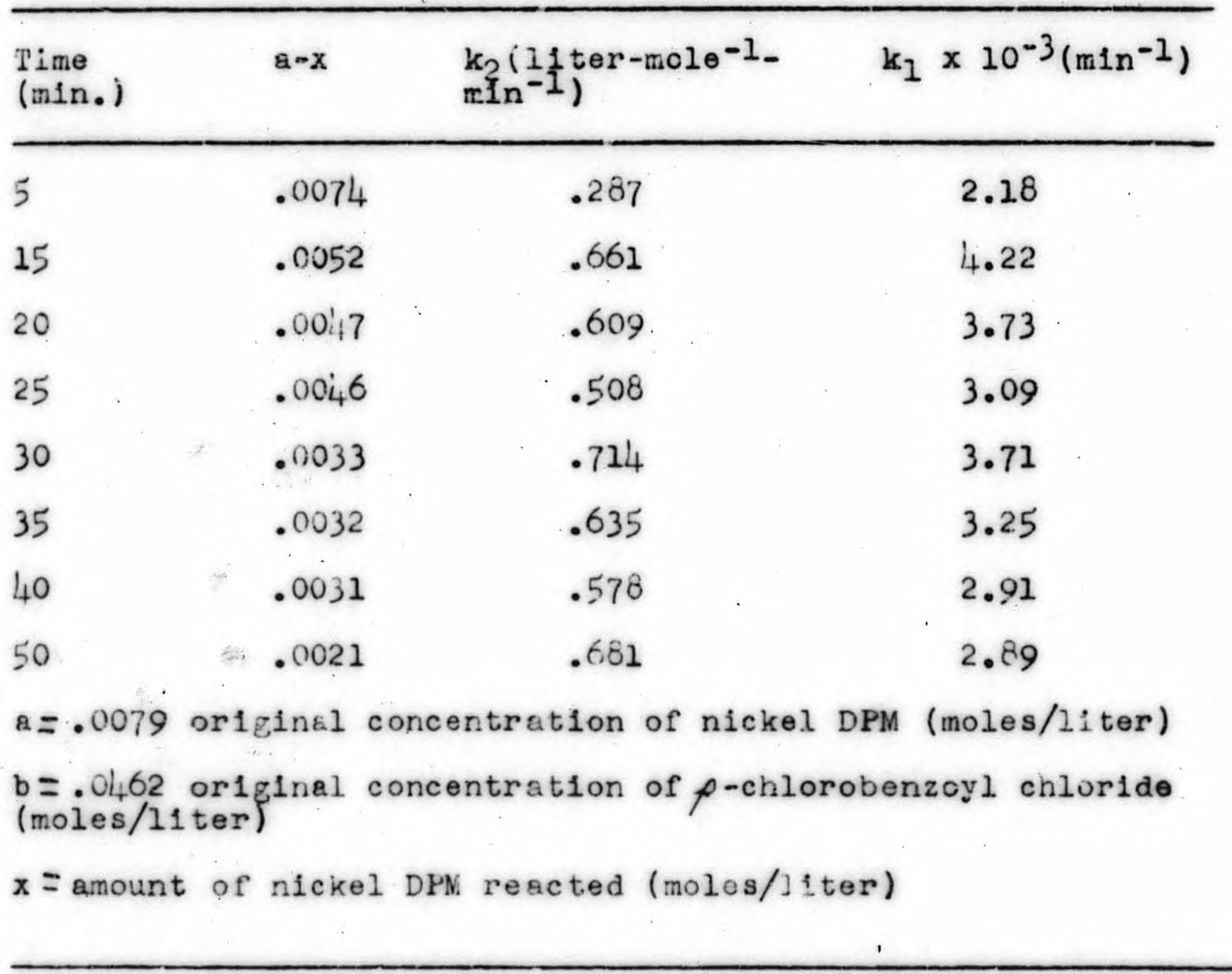

niciel pivalate has been demonstrated, the rates obtained in the $p$-chlorobenzoylation are very probably catalyzed rates. When the $p$-chlorobenzoylation was carried cut in nondegassed systems, nickel pivalate was isolated from the reaction mixture. No nicisel pivalate could be isolated from the benzoylation and $f$-methoxybenzoy lation mixtures al though the appearance of a green color on conpietion of the latter reaction indicated the possible presence of the oxidation product. 


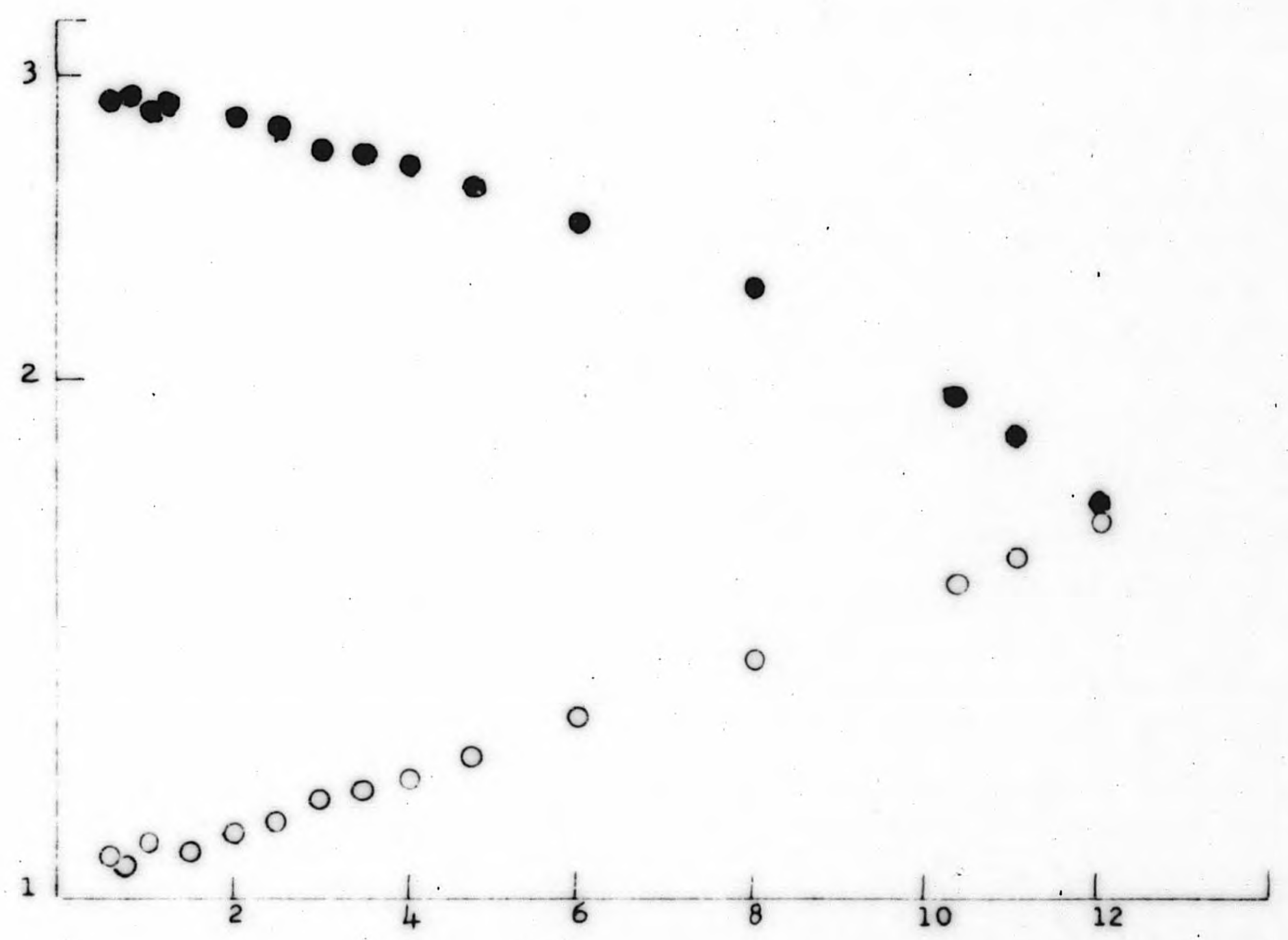

Figure 7. First order $(0)$ and second order $(\bullet)$ plots of $\rho$-methoxybenzoylation ? of nickel DPM. First order $\log \frac{b}{b-2 x} \quad$ Second order $\log \frac{b}{b-2 x}$ 


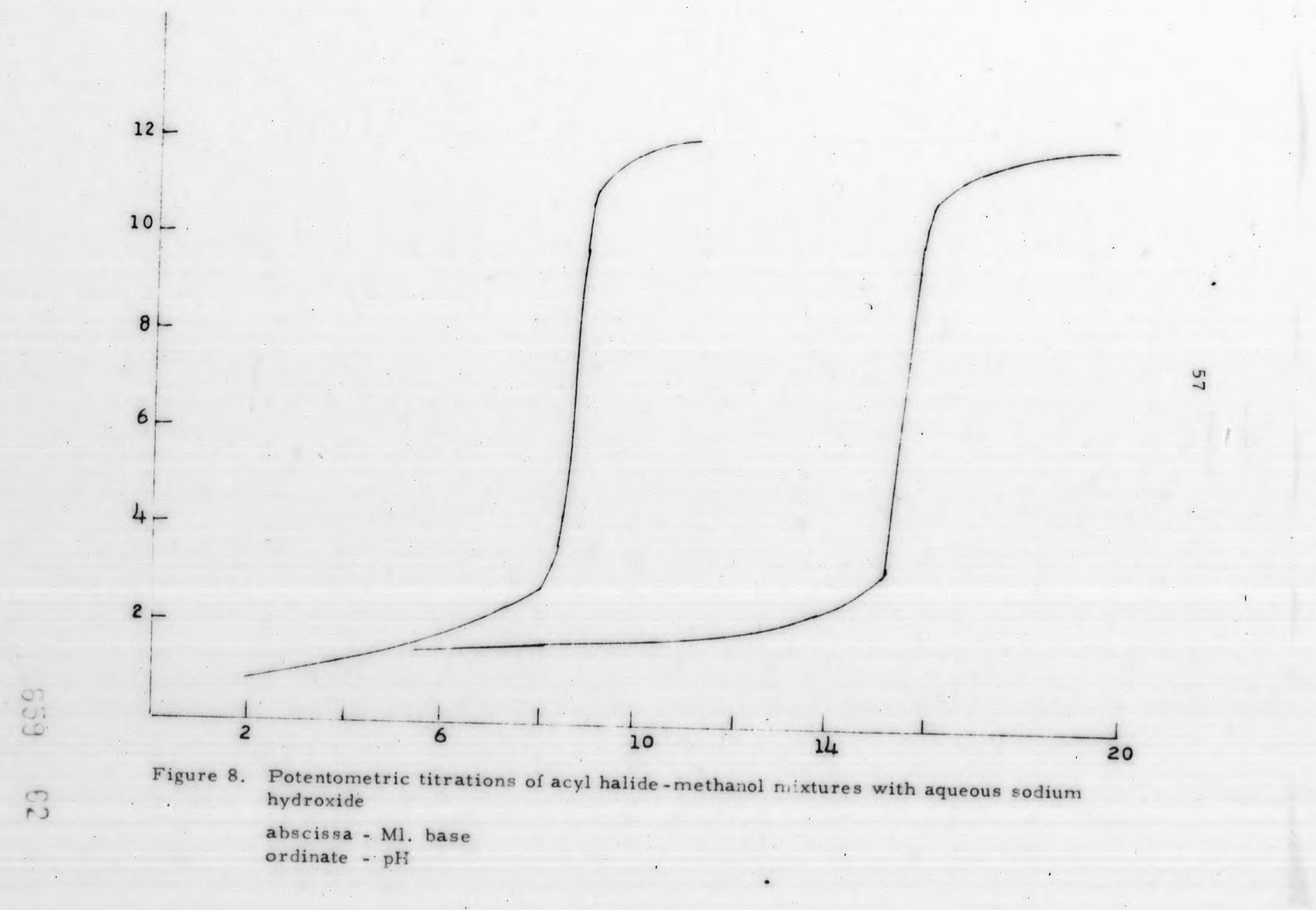


The higher rate of $\rho$-chlorobenzoylation in degassed systems probably means that the latter contained a higher concentration of the catalyzing impurity which is probably the $\rho$-chlorobenzolc acid.

\section{Nechanistic implication}

A mechanism which accounts for the foregolng data might be formulated as follows:

(4) $\mathrm{N1}(\mathrm{DPN})_{2}+2 \mathrm{RCOOH} \longrightarrow 2 \mathrm{H}-\mathrm{DPM}+\mathrm{N1}(\mathrm{RCOO})_{2}$

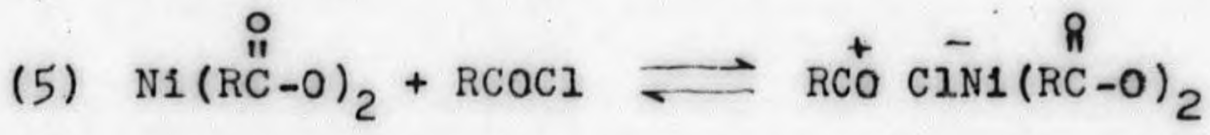

(6) $\mathrm{RCO}^{+} \mathrm{CIN1}\left(\mathrm{RCO}_{2}\right)_{2}+\mathrm{N1}_{(\mathrm{DPM})_{2}} \stackrel{\text { slow }}{\mathrm{RCO}^{*}} \mathrm{Cl}^{-} \mathrm{N} 1(\mathrm{DPN})_{2}$

(7) $\mathrm{RCO}^{+} \mathrm{CI}^{-} \mathrm{N1}(\mathrm{DPN})_{2}+\mathrm{RCOCl} \stackrel{\text { fast }}{\longrightarrow}$ Products

(8) $\stackrel{R C}{R C I}+\mathrm{N1}\left(\mathrm{DPM}_{2}\right)_{2} \stackrel{\text { slow }}{\longrightarrow} \mathrm{RCO} \mathrm{Cl}-\mathrm{N}_{1}(\mathrm{DPM})_{2}$

(9) $\mathrm{RCO}^{+} \mathrm{Cl}^{-} \mathrm{N1}(\mathrm{DPM})_{2} \stackrel{\text { fast }}{\longrightarrow}$ Products

(10) $\mathrm{RCO}^{+} \mathrm{Cl}^{-} \mathrm{N} 1(\mathrm{RCOO})_{2}$ $\stackrel{+}{\mathrm{RCO}^{-}} \mathrm{CI}^{-\mathrm{N} 1(\mathrm{DPN})_{2}}+\mathrm{O}_{2} \rightarrow$ oxidation products

Equation(4) describes the fast reaction of nickel DPM and carboxylic ac1ds. Th1s would account for an in1tial fast rate which then settles down to a slower rate. Equations (5, 6, and 7 )describe the cataiyzed acylation process. If there really is an uncatalyzed reaction, it 
would be visualized as the process in Equations (8)and (9). Since small amounts of acyl halides catalyze the oxidation of nickel DPN, this oxidation might proceed as outlined in Equation (10).

A more thorough investigation of the catalytic effects postulated herein (especially the effects of the carboxylic acids and oxyEen) is obviously needed in order to rigorously prove the mechanisms of alkylations and acylations of metal chelates of $\beta$-diketones.

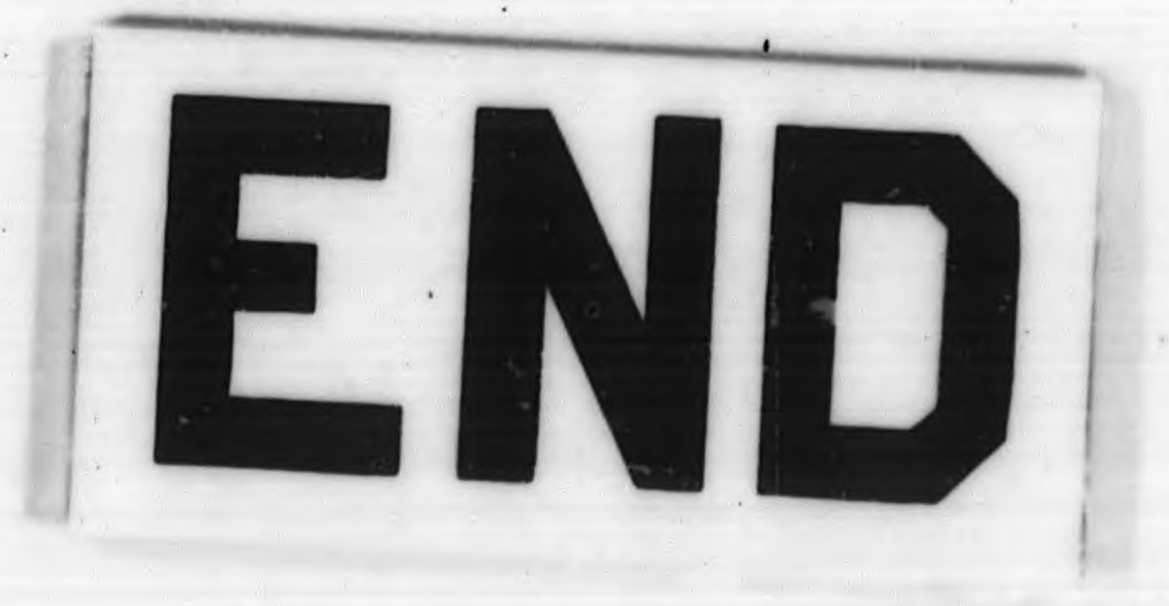

